\title{
$R-2281$
}

\section{FUEL CELL APPLIED RESEARCH:} ELECTROCATALYSIS AND MATERIALS

\author{
QUARTERLY REPORT \\ OCTOBER 1 - DECEMBER 31, 1979
}

May 1980

ELECTROCHEMICAL TECHNOLOGY GROUP ENERGY STORAGE AND CONVERSION DIVISION DEPARTMENT OF ENERGY AND ENVIRONMENT

BROOKHAVEN NATIONAL LABORATORY UPTON, NEW YORK 11973 


\section{DISCLAIMER}

This report was prepared as an account of work sponsored by an agency of the United States Government. Neither the United States Government nor any agency Thereof, nor any of their employees, makes any warranty, express or implied, or assumes any legal liability or responsibility for the accuracy, completeness, or usefulness of any information, apparatus, product, or process disclosed, or represents that its use would not infringe privately owned rights. Reference herein to any specific commercial product, process, or service by trade name, trademark, manufacturer, or otherwise does not necessarily constitute or imply its endorsement, recommendation, or favoring by the United States Government or any agency thereof. The views and opinions of authors expressed herein do not necessarily state or reflect those of the United States Government or any agency thereof. 


\section{DISCLAIMER}

Portions of this document may be illegible in electronic image products. Images are produced from the best available original document. 


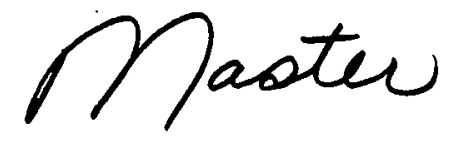

\title{
FUEL CELL APPLIED RESEARCH: ELECTROCATALYSIS AND MATERIALS
}

\author{
QUARTERLY REPORT \\ OCTOBER 1 - DECEMBER 31, 1979
}

S. SRINIVASAN, H.S. ISAaCs, J. MCBreen, W.E. O'Grady, H. OLender, L.J. OLMER, E.J.L. SCHOULER, AND K.V. KORDESCH

May 1980

\section{ELECTROCHEMICAL TECHNOLOGY GROUP ENERGY STORAGE AND CONVERSION DIVISION DEPARTMENT OF ENERGY AND ENVIRONMENT BROOKHAVEN NATIONAL LABORATORY ASSOCIATED UNIVERSITIES, INC.}

UNDER CONTRACT NO. DE-ACO2-76CH00016 WITH THE UNITED STATES DEPARTMENT OF ENERGY

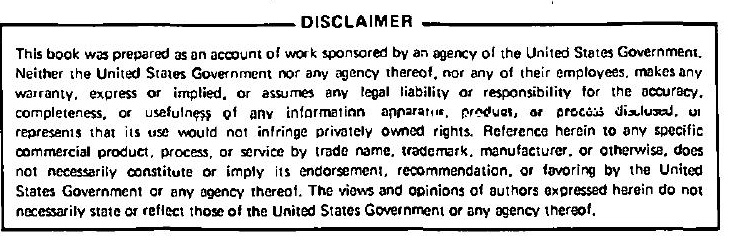




\section{DISCLAIMER}

This rcport was prepared as an account of wurk sponsored by an agency of the United States Guverinment. Neither the I. Iniir.l Silatcs Government nor any agency thereof, nor any of their employees, nor any of their contractors, subcontractors, or their em-

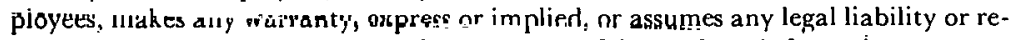
sponsibility for the accuracy, completeness, or usefulness of any information, apparatus, product, or process disclosed, or represents that its use would not infringe privately owned rights. Reference herelin to any suecific commercial product, prncess, or sic viee by trade name, trademark, manufacturer, or otherwise, does not necessarily constitute or imply its endorsement, recommendation, or lavuling by the United States Government or any agency, contractor or subcontractor thereof. The views and opinions of authors expressed herein do not necessarily state or reflect those of the Inited States Government or any agency, contractor or subcontractor thereof.

\section{Printed in the United States of America}

Available from

National Technical Information Service.

\section{U.S. Department of Commerce}

5285 Port Royal Road Springfield, VA 22161

Price: Printed Copy $\$ 7.00$; Microfiche $\$ 3.50$ 
TABLE OF CONTENTS

Page

SUMMARY................................ vii

ACKNOWLEDGMENTS .......................... $\quad x$

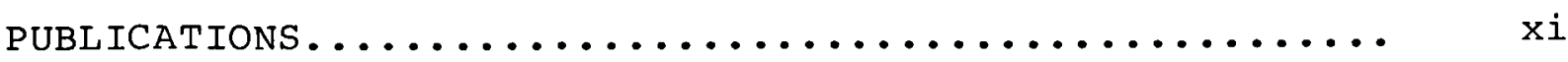

1. ELECTROCATALYSIS OF FUEL CELL REACTIONS

1.1 Carbon Support Materials for Oxygen Electrodes

(H. Olender, J. McBreen, K. V. Kordesch and

S. Srinivasan) .......................

2. SOLID ELECTROLYTE FUEL CELLS

2.1 Air Electrode Kinetics (L. J. Olmer and

H. S. Isaacs) ........................

2.2 Fuel Electrode Kinetics (E.J.L. Schouler

and $\mathrm{H} . \mathrm{S}$. Isaacs)...................... 11

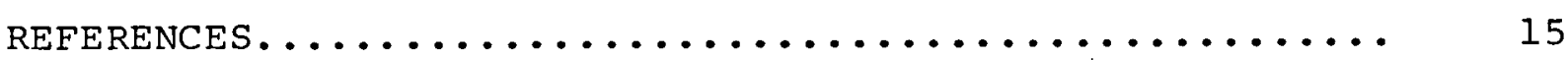

TABLES

I Properties of Cabot Carbons.................. 2

II Floating Test on Cabot Carbon Black Samples.... 3

III Surface Area Data for Platinum on Various

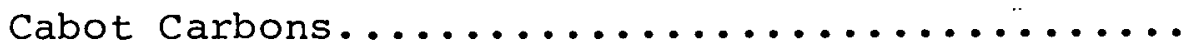

IV Kinetic Parameters for Oxygen Reduction on

Platinum on Various Cabot Carbons...........

FIGURES

la Cyclic Voltammogram on Monarch 13,00 Supporled Platinum Electrode in $85 \% \mathrm{H}_{3} \mathrm{PO}_{4}$ at $25^{\circ} \mathrm{C} \ldots \ldots \ldots$

ib Cyclic Voltammogram on Monarch 1300 Supported Platinum Electrode in $85 \% \mathrm{H}_{3} \mathrm{PO}_{4}$ at $135^{\circ} \mathrm{C}$ After

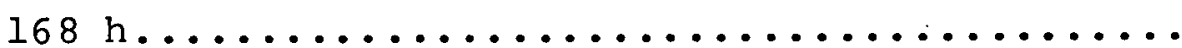

lc Cyclic Voltammogram on Monarch 1300 supported Platinum Elertrode in $85 \% \mathrm{H}_{3} \mathrm{PO}_{4}$ at $135^{\circ} \mathrm{C}$ Arter

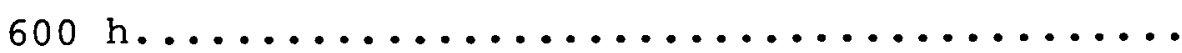


2a Cyclic Voltammogram on CSX 98 supported Platinum Electrode in $85 \% \mathrm{H}_{3} \mathrm{PO}_{4}$ at $25^{\circ} \mathrm{C}$

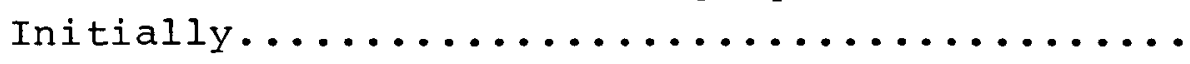

2b Cyclic Voltammogram on CSX 98 supported $\mathrm{Platinum}$ Electrode in $85 \% \mathrm{H}_{3} \mathrm{PO}_{4}$ at $25^{\circ} \mathrm{C}$

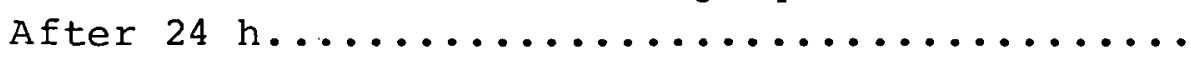

2c Cyclic Voltammogram on CSX 98 supported Platinum Electrode in $85 \% \mathrm{H}_{3} \mathrm{PO}_{4}$ at $135^{\circ} \mathrm{C}$

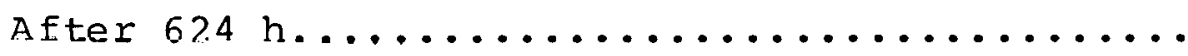

2d Cyclic Voltammogram on $\operatorname{cs} x 98$ supported Platinum Electrode in $85 \circ \mathrm{H}_{3} \mathrm{PO}_{4}$ at $135^{\circ} \mathrm{C}$

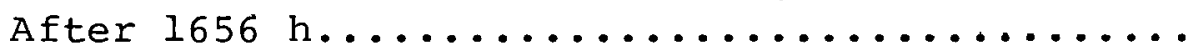

3a Cyclic Voltammogram on Mogul L. Supported Platinum Electrode in $85 \% \mathrm{H}_{3} \mathrm{PO}_{4}$ at $25^{\circ} \mathrm{C} \ldots \ldots \ldots$

3b Cyclic Voltammogram on Mogul L Supported Platinum Electrode in $85 \% \mathrm{H}_{3} \mathrm{PO}_{4}$ at $135^{\circ} \mathrm{C}$

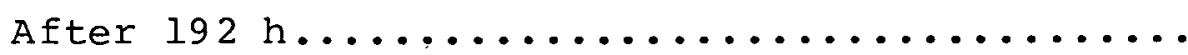

3c Cyclic Voltammogram on Mogul L supported Platinum Electrode in $85 \% \mathrm{H}_{3} \mathrm{PO}_{4}$ at $138^{\circ} \mathrm{C}$

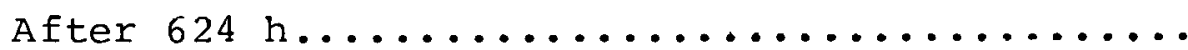

4 a Cyclic Voltammograin on BNL Prepared Vulean $\mathrm{XC}-72 \mathrm{R}$ Supported Platinum Electrode in $85 \%$

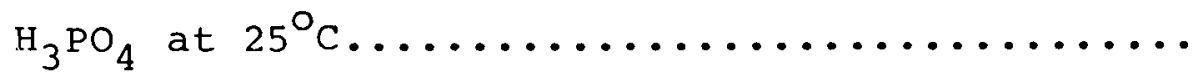

$4 \mathrm{~b}$ Cyclic Voltammogram on BNL Frepared Vulsan $\mathrm{XC}-72 \mathrm{R}$ supported plat1num Electrode in $85 \%$ $\mathrm{H}_{3} \mathrm{PO}_{4}$ at $135^{\circ} \mathrm{C}$ After $624 \mathrm{~h} \ldots \ldots \ldots \ldots \ldots \ldots \ldots \ldots$

4e Cyclic Voltammogram on BNL Prepared Vulcan $\mathrm{XC}-72 \mathrm{n}$ supported P].ati.num Electrode in $85 \%$ $\mathrm{H}_{3} \mathrm{PO}_{4}$ at $144^{\circ} \mathrm{C}$ After $1632 \mathrm{~h} \ldots \ldots \ldots \ldots \ldots \ldots \ldots$

5 a Cyclic Voltammogram on ERC Prepared Vulcan $\mathrm{XC}-72 \mathrm{R}$ Supported Platinum Electrode in $85 \%$ $\mathrm{H}_{3} \mathrm{PO}_{4}$ at $25^{\circ} \mathrm{C} \ldots \ldots \ldots \ldots \ldots \ldots \ldots \ldots \ldots \ldots \ldots \ldots \ldots \ldots \ldots \ldots \ldots \ldots$ 
5b Cyclic Voltammogram on ERC Prepared Vulcan $\mathrm{XC}-72 \mathrm{R}$ Supported Platinum Electrode in $85 \%$ $\mathrm{H}_{3} \mathrm{PO}_{4}$ at $25^{\circ} \mathrm{C}$ After $24 \mathrm{~h} \ldots \ldots \ldots \ldots \ldots \ldots \ldots$.

$5 \mathrm{C}$ Cyclic Voltammogram on ERC Prepared Vulcan $\mathrm{XC}-72 \mathrm{R}$ Supported Platinum Electrode in $85 \%$ $\mathrm{H}_{3} \mathrm{PO}_{4}$ at $135^{\circ} \mathrm{C}$ After $624 \mathrm{~h} \ldots \ldots \ldots \ldots \ldots \ldots \ldots$

$5 d$ Cyclic Voltammogram on ERC Prepared Vulcan $\mathrm{XC}-72 \mathrm{R}$ Supported Platinum Electrode in $85 \%$ $\mathrm{H}_{3} \mathrm{PO}_{4}$ at $144^{\circ} \mathrm{C}$ After $1512 \mathrm{~h} \ldots \ldots \ldots \ldots \ldots \ldots \ldots$

$6 \mathrm{a}$ Cyclic Voltammogram on Regal $660 \mathrm{R}$ supported Platinum Electrode in $85 \% \mathrm{H}_{3} \mathrm{PO}_{4}$ at $25^{\circ} \mathrm{C} \ldots \ldots \ldots$

6b Cyclic Voltammogram on Regal 660R supported Platinum Electrode in $85 \% \mathrm{H}_{3} \mathrm{PO}_{4}$ at $135^{\circ} \mathrm{C}$

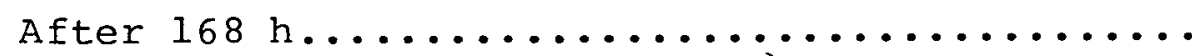

6c Cyclic Voltammogram on Regal 660R Supported Platinum Electrode in $85 \% \mathrm{H}_{3} \mathrm{PO}_{4}$ at $138^{\circ} \mathrm{C}$

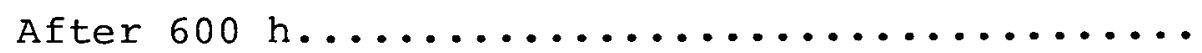

7 Current-Potential Behavior for Oxygen Reduction on Monarch 1300 Supported Platinum Electrode in $85 \% \mathrm{H}_{3} \mathrm{PO}_{4}$ at (a) $25^{\circ} \mathrm{C}$ (Arrows Indicate Increasing on Decreasing Current)

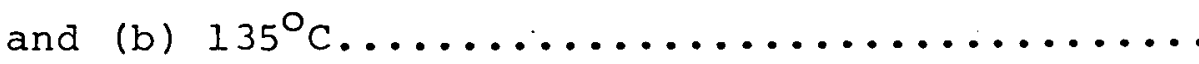

8 Current-Potential Behavior for oxygen Reduction on CSX 98 supported Platinum Elertrode in $85 \% \mathrm{H}_{3} \mathrm{PO}_{4}$ at (a) $25^{\circ} \mathrm{C}$ (Arrows Indicate Hysteresis) and (b) $135^{\circ} \mathrm{C} \ldots \ldots \ldots \ldots \ldots$

9 Current-Potential Behavior for oxygen Reduction on Mogul L Supported Platinum Electrode in $85 \% \mathrm{H}_{3} \mathrm{PO}_{4}$ at $138^{\circ} \mathrm{C} \ldots \ldots \ldots \ldots \ldots \ldots \ldots$

10 Current-Potential Behavior for Oxygen Reduction on BNL Prepared Vulcan XC-72R Supported Platinum Electrode in $85 \% \mathrm{H}_{3} \mathrm{PO}_{4}$ at (a) $25^{\circ} \mathrm{C}$ and (b) $135^{\circ} \mathrm{C}$. 
11 Current-Potential Behavior for Oxygen Reduction on ERC Prepared Vulcan XC-72R Supported Platinum Electrode in $85 \% \mathrm{H}_{3} \mathrm{PO}_{4}$

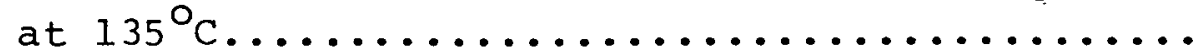

12 Current-Potential Behavior for Oxygen Reduction on Regal 660R Supported Platinum Electrode in $85 \% \mathrm{H}_{3} \mathrm{PO}_{4}$ at (a) $25^{\circ} \mathrm{C}$ and

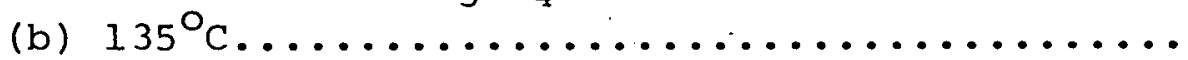

1.3 Polarization Curves of a Platinum Point Contact Electrode Before and After Exposure to $\mathrm{Bi}_{2} \mathrm{O}_{3}$ at $780^{\circ} \mathrm{C}$ and $850^{\circ} \mathrm{C}$, Respectively. Uncontaminated platinum point Electrode Shown for Comparison (Solid Line) ..........................

14 Reaction Impedance as a Function of Reaction Overpotential Resulting from a Rate Controlling Oxygen Adsorption Reaction........

15 Potential Dependent Impedance Diagram of a Fluxed Platinum Paste Flectrode Containing $\mathrm{Bi}_{2} \mathrm{O}_{3} \ldots \ldots \ldots \ldots \ldots \ldots \ldots \ldots \ldots \ldots \ldots \ldots \ldots \ldots$

16a Typical $V$ vs Log I Curves obtained with Pt "Ball-Electrode" at its Interface with $\mathrm{ZrO}_{2} / \mathrm{Y}_{2} \mathrm{O}_{3}$ Electrolyte in $\mathrm{Ar} / \mathrm{H}_{2} \mathrm{O}$ Mixtures. Temperature $1000^{\circ} \mathrm{C} \ldots \ldots \ldots \ldots \ldots \ldots \ldots \ldots . . \ldots \ldots$

16b Typical $v$ vs Log I Curves Obtained with Pt "Ball Electrode" at its Interfacc with 7.ro $\mathrm{O}_{2} / \mathrm{Y}_{2} \mathrm{O}_{3}$ Electrolyte in $\mathrm{Ar} / \mathrm{H}_{2} / \mathrm{H}_{2} \mathrm{O}$ Mixtures. Temperature $1000^{\circ} \mathrm{C} \ldots \ldots \ldots \ldots \ldots \ldots \ldots \ldots$

17 V vs Log I Curves for a Pt Electrode at its Interface with $\mathrm{ZrO}_{2} / \mathrm{Y}_{2} \mathrm{O}_{3}$ Electrolyte at Constant $\mathrm{P}_{\mathrm{H}_{2} \mathrm{O}}$ and Varying $\mathrm{P}_{\mathrm{H}_{2}} \cdot$ Temperature $1000^{\circ} \mathrm{C}$ 
18 Dependence of $\mathrm{I}_{\ell, \mathrm{H}_{2}}$ for Different $\mathrm{p}_{\mathrm{H}_{2} \mathrm{O}}$

on a Pt Electrode at its Interface with

$\mathrm{ZrO}_{2} / \mathrm{Y}_{2} \mathrm{O}_{3}$ Electrolyte. Temperature $1000^{\circ} \mathrm{C} \ldots \ldots \ldots \ldots \ldots \ldots \ldots \ldots \ldots \ldots$

$19 \mathrm{I}_{\ell, \mathrm{H}_{2}}^{-1}$ vs $\mathrm{P}_{\mathrm{H}_{2} \mathrm{O}} / \mathrm{P}_{\mathrm{H}_{2}}$ Plots for a Pt Electrode at its Interface with $\mathrm{ZrO}_{2} / \mathrm{Y}_{2} \mathrm{O}_{3}$ Electrolyte. Temperature $1000^{\circ} \mathrm{C} . \ldots \ldots \ldots \ldots$ 
1. ELECTROCATALYSIS OF FUEL CELL REACTIONS

Five types of carbon obtained from Cabot Laboratories (Cabot designation of carbons-Monarch 1300, CSX 98, Mogul L, Vulcan XC$72 \mathrm{R}$ and Regal 660R) were compared as supports for platinum electrocatalysts. Experiments were conducted to determine the wetting characteristics of the carbon as a function of temperature and the effects of these carbons on the electrocatalytic activity of supported platinum for oxygen reduction. The latter was investigated by a cyclic voltammetry technlyue. Tlie changes in tho eloctrnehemically active surface areas on increasing the temperature from $25^{\circ}$ to $135^{\circ} \mathrm{C}$ and after carrying out oxygen reductiun weite measurcd from the hydrogen desorption charge in the cyclic voltammograms.

The electrode, prepared with the carbon Regal 660R, showed excellent stability at both temperatures. The Tafel slope for oxygen reduction was $70 \mathrm{mV}$ and was independent of temperature. Regal $660 \mathrm{R}$ shows more promise as a carbon support than Vulcan $\mathrm{XC}-72 \mathrm{R}$.

\section{SOLID ELECTROLYTE FUEL CELLS}

The influence of electrode material on oxygen renurticsn $\mathrm{ki}=$ netics and the reaction mechanism on platinum at interfaces with solid electrolytes were investigated. To overcome problems connected with morphologic changes of porous electrodes, point contact electrodes were used. Direct current and alternating rurrent impedance techniques were uscd. The results for oxygen reduction electrode kinetics showed a dependence on the material, its method of surface preparation, purity, and direction of potential change. The order of electrocatalytic activity for oxygen reduction was attained on the basis of current per unit length in the triphase region. Of the materials tested, $\mathrm{Rh}$ showed high electrocatalytic activities, whereas Au was a relatively poor electrocatalyst. The effects of impurities were ascertained. From the ac and dc 
studies, it was shown that the rate determining step for oxygen reduction, when impurities such as bismuth oxides are present, is the dissociative adsorption of oxygen.

Studies on the oxidation of $\mathrm{H}_{2}$ on platinum and gold interfaces with the zirconia electrolyte interface were begun. Experiments on single contact ball electrodes of platinum were used. Slow potential sweep techniques (scan rate $5 \mathrm{mV} / \mathrm{sec}$ ) were used. An electrochemical oxygen meter with an air reference was used to measure the fuel electrode composition (e.g., $\mathrm{H}_{2} / \mathrm{H}_{2} \mathrm{O}$ ). As expected with increases in hydrogen concentration, the open circuit potential decreases and the limiting current increases for hydrogen oxidation. The oxygen evolution current was not affected by the hydrogen concentration. A linear relation between the limiting current and hydrogen concentration was observed. Experiments with gold as the test electrode are in progress. 


\section{ACKNOWLEDGMENTS}

The authors wish to thank the following:

- Mr. M. Zlotnick, Department of Energy Program Manager, for his continued guidance and interest;

- Dr. M. Warshay and Dr. M. Lauver, NASA-Lewis Research Center, for the technical management responsibility on the phosphoric acid fuel cell program;

- Mr. B. Manowitz, Mr. T. E. O'Hare and Mr. F. J. Salzano, Bronkhaven National Laboratory, for their interest and encouragemont;

- Dr. P. F. Gridley, Cabot Corporation, for the supply of the five types of carbon blacks;

- Dr. B. S. Baker, Energy Research Corporation, for providing ERC fuel cell electrodes and for helpful discussions;

- Professor B. E. Conway, University of Ottawa, Eor valuable discussions and suggestions; and

- Mrs. V. Diebel for her efforts in the preparation of this report. 


\section{PUBLICATIONS}

January 1, 1979 - December 31, 1979

1. Yang, C. Y. and Isaacs, H. S., "Materials Compatibility in a High Temperature Solid Electrolyte System," Extended Abstracts, Spring Meeting of the Electrochemical Society, Boston, Massachusetts, May 6-11, 1979, The Electrochemical Society, Inc., Princeton, New Jersey, Vol. 79-1, pp. 7-8 (BNL 25553).

2. O'Grady, W. E., Taylor, E. J. and Srinivasan, S., "Oxygen Reduction on Platinum in Trifluoromethanesulfonic Acid and Phosphoric Acid," ibid, pp. 883-5 (RNT, 25554).

3. Kordesch, K. V., Kissel, G., Kulesa, F., Taylor, E. J., McBreen, J. and Srinivasan, S., "Evaluation of Improved Cathodes in Alkaline Fuel Cells," ibid, pp. 48-9 (BNL 25597).

4. McBreen, J., O'Grady, W. E., Olender, H., Taylor, E. J. and Srinivasan, S., "Electrocatalysis of the Oxygen Reduction Reaction in Phosphoric Acid," National Fuel Cell Seminar Abstracts, Bethesda, Maryland, June 26-28, 1979, p. 56 (BNL 26001).

5. Isaacs, H. S., Olmer, L. J. and Srinivasan, S., "Overpotential Behavior of Oxide Cathodes on Solid Electrolytes," ibid, p. 60 (BNL 26000).

6. O'Grady, W. E. and Taylor, E. J., "Electrolytes for Enhanced $\mathrm{O}_{2}$ Reduction," (BNL 26032).

7. Srinivasan, S., Isaacs, H. S., O'Grady, W. E., Olender, H. and olmer, L. J., Fuel Cell Applied Research: Electrocatalysis and Materials, Semi-Annual Report, January 1 - June 30, 1978, Brookhaven National Laboratory, Upton, New York 11973, 1979 (BNL 51038/FC-3).

8. McBreen, J., Taylor, E. T., Kordesch, K. V., Kissel, G., Kulesa, F. and Srinivasan, S., Development of Fuel Cell Technology for Vehicular Applications, Annual Report, October I, 1977 - September 30, 1978, Brookhaven National Laboratory, New York 11973, 1979 (BNL 51047/FCT-1).

9. Srinivasan, S. and O'Grady, W. E., "Oxygen Electrode Reaction: Influence of Electronic and Geometric Properties," Abstracts of AIME Annual Meeting, Las Vegas, Nevada, February 1980 (BNI 26627).

10. Olmer, L. J. and Isaacs, H. S., "Determination of Current Transients During Polarization," Extended Abstracts, Fall Meeting of the Electrochemical Society, Los Angeles, California, October 14-19, 1979, The Electrochemical Society, Inc., Princeton, New Jersey, Vol. 79-2, pp. 368-70 (BNL 26626).

$$
-x i-
$$


Publications (Cont'd)

11. Isaacs, H. S. and Olmer, L. J., "The Overpotential Behavior of Electrode Materials at Interfaces with $\mathrm{ZrO}_{2}-\mathrm{Y}_{2} \mathrm{O}_{3}$ Electrolytes," ibid, pp. 371-2 (BNI 26628).

12. O'Grady, W. E., Olender, H. and Srinivasan, S., "In-Situ Regeneration of the Pt Surface on Carbon supported Electrodes," ibid, pp. 531-2 (BNL 26630).

13. Yang, C. Y. and Isaacs, H. S., "Oxygen Diffusion in Interconnecting Materials in High Temperature Solid Electrolyte Systems," ibid, p. 367 (BNL 26632).

14. Srinivasan, S., Isaacs, H. S., O'Grady, W. E., Olender, H., Olmer, L. J., Daube, K. and Kordesch, K. V., Fuel Cell Applied Research: Electrocatalysis and Materials, Quarterly Report, July 1 - September 30, 1978, Brookhaven National Laboratory, Upton, New York 11973, 1979 (BNL 51053/FC-4).

15. Srinivasan, S., Isaacs, H. S., McBreen, J., O'Grady, W. E., Olender, H., Olmer, L. J., Taylor, E. J., Yang, C. Y. and Wirtz, G. P., Fuel Cell Applied Research: Electrocatalysis and Materials, Quarterly Report, October 1 - December 31, 1978, Brookhaven National Laboratory, Upton, New York 11973, 1979 (BNL 51072/FC-5).

16. Isaacs, H. S. and Olmer, L. J., "Oxygen Electrocatalysis and Electrode Reactions with Zirconia Electrolytes," American Ceramic Society Bulletin 59, 379 (1980).

17. Srinivasan, S., Isaacs, H. S., McBrcen, J., O'frady, W. E., Olender, H.: Olmer, L. J. dild Taylor, E. J., Firel Cell Applied Research: Electrocatalysis and Materials, Quarterly Report, January 1 - March 31, 1979, Brookhaven National Laboratory, Upton, New York 11973, 1979 (BNL 51144/FC-6).

1.8. Adzic, R. R., O'Grady, W. E. and Srinivasan, S., "Oxidation of $\mathrm{HCOOH}$ on $(100),(110)$ and (111) Singlc Crystal Platinum Elactrnies," Surface Science 94, L191 (1980). 
FUEL CELL APPLIED RESEARCH:

ELECTROCATALYSIS AND MATERIALS

1. ELECTROCATALYSTS OF FUEL CELL REACTIONS

1.1 Carbon Support Materials for Oxygen Electrodes

(H. Olender, J. McBreen, K. V. Kordescht and

S. Srinivasan)

The trend towards operation of phosphoric acid fuel cells at higher temperatures and pressures, from the point of view of improving power plant performance, has resulted in a search for more stable carbon support materials for platinum oxygen electrodes $(1,2)$. Hitherto, Vulcan XC-72R carbon from Cabot Corporation has been used as support for the anode and cathode electrocatalysts. In the present investigation, the effect of various alternate carbons on oxygen reduction and electrode stability was investigated. The alternate carbons were chosen on a visit by $K$. V. Kordesch and S. Srinivasan to Dr. P. F. Gridley, Manager, Applications Division, Special Blacks Division, Cabot Corporation, Billerica, MA 01821. Five furnace blacks were selected with a wide range of physical and chemical properties. The properties considered were surface area, particle size, electrical resistivity, volatile content and $\mathrm{pH}$. The data for the various carbons are summarized in Table I. The wetting characteristics in $85 \% \mathrm{H}_{3} \mathrm{PO}_{4}$ were evaluated using a simple floating test. An aliquot of the carbon was added to $85 \%$ $\mathrm{H}_{3} \mathrm{PO}_{4}$ at $25^{\circ} \mathrm{C}$, and the solution was slowly heated to $120^{\circ} \mathrm{C}$. The amount of carbon still afloat was monitored with increasing temperature. The observations are summarized in Table II. The CSX98 carbon displayed the lowest wetting characteristics.

Preliminary evalualiuns of oxygen reduction on platinum on these various carbons were carried out in $85 \% \mathrm{H}_{3} \mathrm{PO}_{4}$ using PTFE bonded electrodes operated in the flooded mode. The electrode

FProfessor of Inorganic Technology, Techn. Universität Graz, Graz, Austria; Consultant on BNL Fuel Cell program. 
Table I

\begin{tabular}{|c|c|c|c|c|c|}
\hline $\begin{array}{c}\text { Cabot } \\
\text { Designation }\end{array}$ & $\begin{array}{c}\text { Surface } \\
\text { Area } \\
\mathrm{m}^{2} / \mathrm{g}\end{array}$ & $\begin{array}{c}\text { Particle } \\
\text { Size } \\
\text { R }\end{array}$ & $\begin{array}{l}\text { Electrical } \\
\text { Resistivity } \\
\text { (Dry) }\end{array}$ & $\begin{array}{c}\text { Volatile } \\
\text { Content } \\
\frac{\circ}{0}\end{array}$ & $\mathrm{pH}$ \\
\hline Monarch 1300 & 560 & 130 & Medium & 9.5 & 3.3 \\
\hline CSZ 98 & $\mathrm{~S}$ i $\mathrm{m}$ & $i l$ a $r$ & $t \circ M \circ n a$ & $r c h \quad 13$ & 00 \\
\hline Mogul L & 138 & 240 & High & 5.0 & 3.4 \\
\hline Vulcan $x C-72 R$ & 254 & 300 & Lowest & 2.0 & 5.0 \\
\hline Regal 660R & 112 & 210 & Low & 1.0 & 7.5 \\
\hline
\end{tabular}

fabrication was as follows. The carbon was mixed with Teflon T- 30 suspension to yield a $12 \mathrm{w} / \mathrm{O}$ PTFE content. The mixture was rolled on to a carbon substrate paper, obtained from Energy Research Corporation. The average carbon/PTFE layer thickness was 0.003 inches. The samples were pressed at $0.02 \mathrm{ton} / \mathrm{cm}^{2}$ and dried in an oven at $315^{\circ} \mathrm{C}$ for 15 minutes. The samples were catalyzed by brushing on a layer of 1 \% chloroplatinic acid till a loading of $1 \mathrm{mg} / \mathrm{cm}^{2}$ was obtained. The samples were dried agaill at $150^{\circ} \mathrm{C}$ for 15 minutes and then dipped into a $1 \%$ solution of sodium borohydride to reduce the platinum oxide. The electrodes were then mounted on gold grid current collectors. A platinum catalyzed vulcan $x C-72 R$ electrode from Energy Research Corporation was included in the test. This electrode was designed for gas feed operation and had a PTFE content of $\sim 25 \mathrm{w} / \mathrm{o}$, a catalyst loading of $0.35 \mathrm{mg} / \mathrm{cm}^{2}$ and a catalyst layer thlckness of 0.010 inches.

All electrodes were mounted in PTFE beaker cells with large platinum screen counter electrodes and dynamic hydrogen reference electrodes. The electrolyte was $85 \% \mathrm{H}_{3} \mathrm{PO}_{4}$, which was purified by a combination of a hydrogen peroxide/pre-electrolysis treatment. oxygen reduction studies were carried out while bubbling oxygen through the electrolyte. The electrolyte was purged with nitrogen prior to cyclic voltammetry studies. Data were obtained at $25^{\circ} \mathrm{C}$ prior to increasing the temperature to $135^{\circ} \mathrm{C}$. 
Table II

\begin{tabular}{|c|c|c|c|}
\hline \multirow[b]{3}{*}{${ }^{T}{ }_{C}^{m p}}$. & \multicolumn{3}{|c|}{ FLOATING TEST ON CABOT CARBON BLACK SAMPLES } \\
\hline & Observations & 5 on Settling Rate of Various & Carbons \\
\hline & Mogul & Monarch & $\operatorname{csx}$ \\
\hline 27 & $\begin{array}{l}\text { Film of carbon } \\
\text { afloat, most } \\
\text { particles sus- } \\
\text { pended in liq- } \\
\text { uid at bottom. }\end{array}$ & $\begin{array}{l}50 \% \text { carbon afloat, large } \\
\text { particles suspended in } \\
\text { liquid, some settle at } \\
\text { bottom. }\end{array}$ & $\begin{array}{l}\text { Most carbon } \\
\text { afloat, few small } \\
\text { particles sus- } \\
\text { pended in liquid. }\end{array}$ \\
\hline 33 & $\begin{array}{l}\text { Thin film of } \\
\text { carbon afloat, } \\
\text { few particles } \\
\text { suspended in } \\
\text { liquid, most } \\
\text { at bottom. }\end{array}$ & $\begin{array}{l}\text { Thin film of carbon afloat, } \\
\text { small particles suspended } \\
\text { in liquid, most at bottom. }\end{array}$ & $\begin{array}{l}\text { Most carbon still } \\
\text { afloat, few med- } \\
\text { medium particles } \\
\text { suspended in } \\
\text { liquid. }\end{array}$ \\
\hline 48 & $\begin{array}{l}\text { Thin film of car } \\
\text { particles suspen } \\
\text { bottom. }\end{array}$ & $\begin{array}{l}\text { cbon atop liquid, few small } \\
\text { nded, most have settled to }\end{array}$ & $\begin{array}{l}\text { Carbon afloat, } \\
\text { start to diminish, } \\
\text { few large particles } \\
\text { at bottom. }\end{array}$ \\
\hline 57 & & Same & $\begin{array}{l}\text { Large particles } \\
\text { still fall, most } \\
\text { still afloat. }\end{array}$ \\
\hline 63 & & Same & $\cdot$ \\
\hline 75 & & Same & $\begin{array}{l}50 \% \text { carbon still } \\
\text { afloat. }\end{array}$ \\
\hline 98 & & Same & $\begin{array}{l}\text { Most particles at } \\
\text { bottom. }\end{array}$ \\
\hline 120 & All particles ha & ave settled to the bottom. & \\
\hline
\end{tabular}

Cyclic voltammetry results for the various carbons are presented in Figures 1-6. The surface area data, as measured by hydrogen desorption, are given in Table III. The changes which occurred with time are also noted. Current-potential plots for oxygen redúction on platinum on the various carbons are given in Figures 7-12. The kinetic parameters for oxygen reduction are summarized in Table IV.

It is difficult to compare the results obtained on BNL prepared electrodes with those obtained from Energy Research Corporation (ERC) because of the highly hydrophobic nature of the latter 
Table III

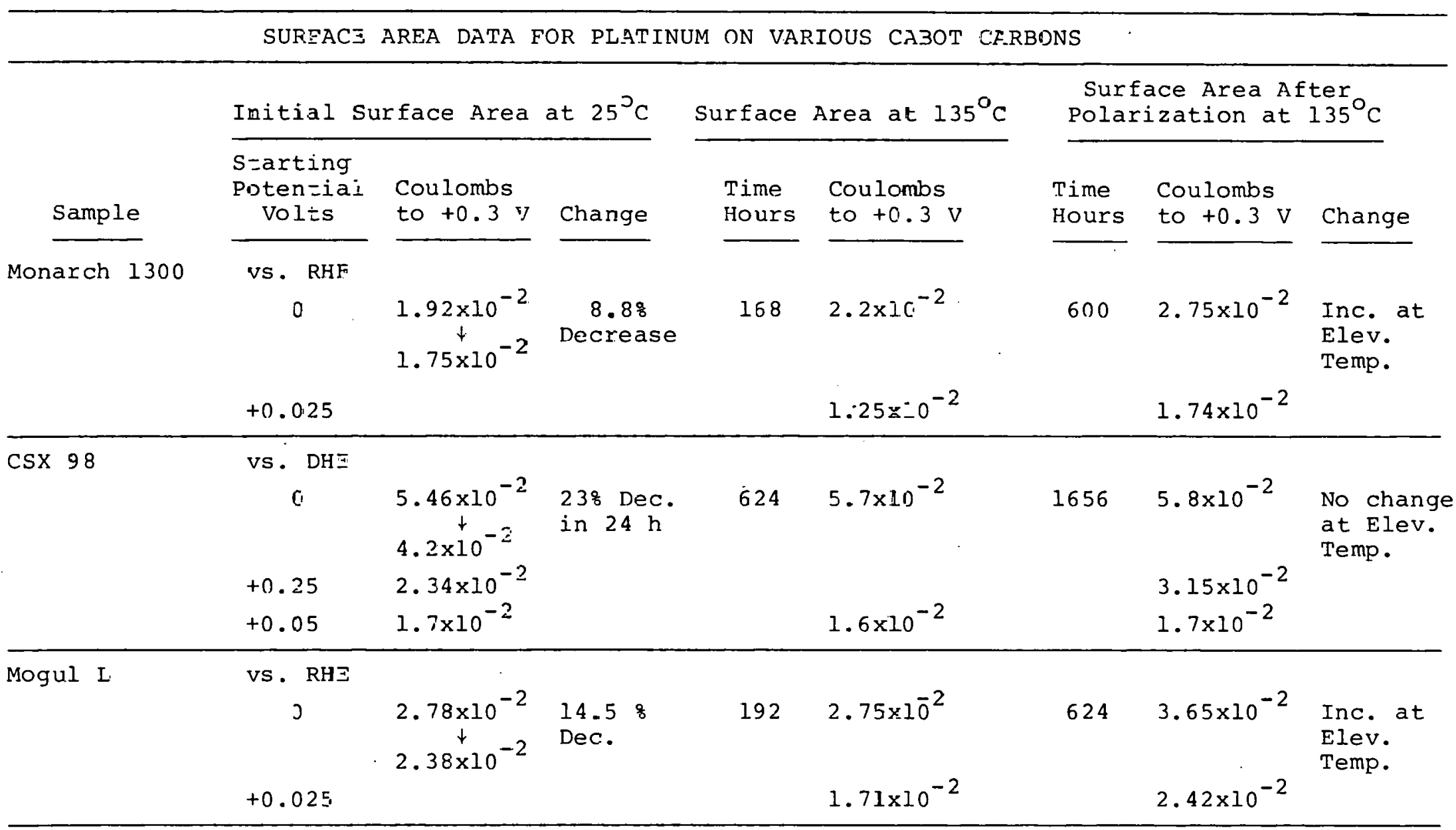


Table III (Cont.)

SURFACE AREA DATA FOR PLATINUM ON VARIOUS CABOT CARBONS

\begin{tabular}{|c|c|c|c|c|c|c|c|c|}
\hline \multirow[b]{2}{*}{ Sample } & \multicolumn{3}{|c|}{ Initial Surface Area at $25^{\circ} \mathrm{C}$} & \multicolumn{2}{|c|}{ Surface Area at $135^{\circ} \mathrm{C}$} & \multicolumn{3}{|c|}{$\begin{array}{l}\text { Surface Area After } \\
\text { Polarization at } 135^{\circ} \mathrm{C}\end{array}$} \\
\hline & $\begin{array}{l}\text { Starting } \\
\text { Potential } \\
\text { Volts }\end{array}$ & $\begin{array}{l}\text { Coulombs } \\
\text { to }+0.3 \mathrm{~V}\end{array}$ & Change & $\begin{array}{l}\text { Time } \\
\text { Hours }\end{array}$ & $\begin{array}{l}\text { Coulombs } \\
\text { to }+0.3 \mathrm{~V}\end{array}$ & $\begin{array}{l}\text { Time } \\
\text { Hours }\end{array}$ & $\begin{array}{l}\text { Coulombs } \\
\text { to }+0.3 \mathrm{~V}\end{array}$ & Change \\
\hline $\begin{array}{l}\text { Vulcan XC-72R } \\
\text { (BNL Sample) }\end{array}$ & $\begin{array}{c}\text { vs. RHE } \\
0\end{array}$ & $\begin{array}{c}7.4 \times 10^{-2} \\
\downarrow \\
5.7 \times 10^{-2}\end{array}$ & $\begin{array}{l}23 \% \text { Dec. } \\
\text { in } 24 \mathrm{~h}\end{array}$ & 524 & $4.85 \times 10^{-2}$ & 1632 & $3.9 \times 10^{-2}$ & $\begin{array}{l}19.5 \% \\
\text { Dec. at } \\
\text { Elev. } \\
\text { Temp. }\end{array}$ \\
\hline & -0.05 & & & & & & $7.8 \times 10^{-2}$ & $\begin{array}{l}478 \text { Over- } \\
\text { all Dec. }\end{array}$ \\
\hline $\begin{array}{l}\text { Vulcan XC-72R } \\
\text { (ERC Sample) }\end{array}$ & $\begin{array}{c}\text { VS. RHE } \\
0 \\
-0.05\end{array}$ & $\begin{array}{c}1.7 \times 10^{-2} \\
\downarrow \\
3.0 \times 10^{-2}\end{array}$ & $\begin{array}{l}768 \text { Inc. } \\
\text { due to } \\
\text { Wetting }\end{array}$ & 624 & $\begin{array}{l}1.95 \times 10^{-1} \\
3.0 \times 10^{-1}\end{array}$ & 1512 & $\begin{array}{l}1.75 \times 10^{-1} \\
2.5 \times 10^{-1}\end{array}$ & $\begin{array}{l}10 \% \text { Dec. } \\
\text { at Elev. } \\
\text { Temp. }\end{array}$ \\
\hline Regal $660 \mathrm{R}$ & $\begin{array}{c}\text { vs. DHE } \\
0 \\
+0.025 \\
+0.05\end{array}$ & $\begin{array}{l}6.5 \times 10^{-2} \\
4.1 \times 10^{-2} \\
3.1 \times 10^{-2}\end{array}$ & Stable & 168 & $\begin{array}{l}6.3 \times 10^{-2} \\
4.4 \times 10^{-2}\end{array}$ & 600 & $\begin{array}{l}6.7 \times 10^{-2} \\
4.42 \times 10^{-2} \\
2.94 \times 10^{-2}\end{array}$ & $\begin{array}{l}\text { Very Stable } \\
\text { No Changes }\end{array}$ \\
\hline
\end{tabular}




\begin{tabular}{|c|c|c|c|c|c|c|c|c|}
\hline \multirow{3}{*}{ Sample } & \multicolumn{8}{|c|}{$\begin{array}{l}\text { KINETIC PARAMETERS FOR OXYGEN REDUCTION } \\
\text { ON PLATINUM ON VARIOUS CABOT CARBONS }\end{array}$} \\
\hline & \multicolumn{2}{|c|}{$\begin{array}{l}\text { Tafel Slope b } \\
\text { Volts }\end{array}$} & \multicolumn{2}{|c|}{$\begin{array}{c}\text { Exchange Current } \\
\text { Density }{ }^{\mathrm{A} / \mathrm{cm}^{2}}\end{array}$} & \multicolumn{2}{|c|}{$\begin{array}{c}\text { Transfer } \\
\text { Coefficient } \\
\alpha\end{array}$} & \multicolumn{2}{|c|}{$\begin{array}{c}\text { Potential at } \\
10^{-4} \mathrm{~A} / \mathrm{cm}^{2} \\
\text { Volts }\end{array}$} \\
\hline & $25^{\circ} \mathrm{C}$ & $135^{\circ} \mathrm{C}$ & $25^{\circ} \mathrm{C}$ & $135^{\circ} \mathrm{C}$ & $25^{\circ} \mathrm{C}$ & $135^{\circ} \mathrm{C}$ & $25^{\circ} \mathrm{C}$ & $135^{\circ} \mathrm{C}$ \\
\hline Monarch 1300 & 0.105 & 0.085 & $5 \times 10^{-10}$ & $2 \times 10^{-7}$ & 0.56 & 0.95 & --- & 0.87 \\
\hline $\operatorname{csx} 98$ & 0.110 & 0.085 & $5 \times 10^{-9}$ & $5 \times 10^{-7}$ & 0.54 & 0.95 & --- & 0.92 \\
\hline Mogul I & $--\infty$ & 0.080 & $--\cdots$ & $2 \times 10^{-7}$ & ---- & 1.0 & $---\infty$ & 0.82 \\
\hline $\begin{array}{l}\text { Vulcan } \mathrm{XC}-72 \mathrm{R} \\
\text { (BNL Sample) }\end{array}$ & 0.080 & 0.060 & $3 \times 10^{-9}$ & $2 \times 10^{-8}$ & 0.74 & 1.35 & $-m-$ & 0.85 \\
\hline $\begin{array}{l}\text { Vulcan XC-72R } \\
\text { (ERC Sample) }\end{array}$ & $-\infty-$ & 0.070 & ---- & $1 \times 10^{-7 \prime}$ & --- & 1.16 & ---- & 0.60 \\
\hline Regal $660 \mathrm{R}$ & 0.070 & 0.070 & $5 \times 10^{-11}$ & $1 \times 10^{-7}$ & 0.84 & 1.16 & 0.46 & 0.91 \\
\hline
\end{tabular}

electrode. The increase in the hydrogen desorption charge for the ERC electrode with successive cycles (Figure 2c) is due to an increased wetting of the electrode.

It is possible, however, to make intercomparisons between the electrodes prepared at BNL. One salient feature was the extreme stability of the hydrogen desorption charge on platinum supported on Regal 660R (Table III). On increasing the temperature from $25^{\circ}$ to $135^{\circ} \mathrm{C}$, the hydrogen adsorption and desorption peaks were shifted to more negative potentials. It is, however, interesting to note that the hydrogen desorption charge is the same at both temperatemperatures.

The kinetio data for oxygen reduction on platinum supported on the various carbons exhibit differences. Both the Monarch 1300 and the CSX 98 material displayed high Tafel slopes ( $100 \mathrm{mV} / \mathrm{dec}-$ ade at. $25^{\circ} \mathrm{C}$ ). The Regal $660 \mathrm{R}$ material had a low Tafel slope of $70 \mathrm{mV} /$ decade which did not change on increasing the lemperature from $25^{\circ}$ to $135^{\circ} \mathrm{C}$. 
In the next quarter, the corrosion resistance of the carbons will be evaluated using cyclic voltammetry.

2. SOLID ELECTROLYTE FUEL CELLS

\subsection{Air Electrode Kinetics (L. J. Olmer and H. S. Isaacs)}

Electrochemical devices incorporating solid oxide electrolytes are being considered for use as high temperature fuel cells. With the advance of thin film fuel cell technology (3), electrolyte thicknesses have been reduced to about $30 \mathrm{\mu m}$ leaving interfacial polarization losses as a major limiting factor in fuel cell performance (4). Numerous electrode reaction mechanisms have been proposed (5), but it is still not clear which reactions control the rates of oxygen reduction. The contributions of the electrode and electrolyte components in controlling. the air electrode reaction were studied and the interfacial behavior was characterized using polarization and ac impedance measurements.

In order to establish whether the electrode materials had any influence on the oxygen electrode kinetics, various electrode materials were tested with a stabilized zirconia test cell. The cell consisted of a $2 \mathrm{~cm}$ length by $1 \mathrm{~cm}$ wide section of slipcast (sc) $\mathrm{ZrO}_{2}$ containing 4 mole-\% $\mathrm{Y}_{2} \mathrm{O}_{3}$ with annealed platinum paste auxiliary and reference electrodes each having a $0.25 \mathrm{~cm}^{2}$ area and both situated on one side of the electrolyte. Electrode morphology effects were overcome by the use of point contart eloctrodes. The electrodes were formed by either melting the tips of the metal wires with a methane/oxygen flame until a small sphere developed or in the case of the oxide electrode, the tips were rounded on silicon carbide paper. The point contact electrodes were attached to a $35 \mathrm{~cm}$ length of platinum lead wire reinforced with an alumina tube so that the test electrode could be pressed on the electrolyte at the operating temperature. The polarization curves for 12 electrode materials were obtained. The results showed a major dependence of the current on the electrode material 
and its surface preparation with a dependence on the direction of potential changes (or hysteresis), a Tafel slope for the oxygen evolution reaction, and inflections at potentials corresponding to oxygen reduction.

The comparison of the catalytic performances of each electrode material was based on the assumption that the current could be normalized to the electrode contact circumference and that the electrode contact radius could be calculated according to Newman's (6) analysis in treating the electrode as a conductor embedded in a semi-infinite insulating plane (in this case the electrolyte). Following this procedure, the specific curients wore calrulated at an overpotential equal to $-100 \mathrm{mV}$. Gathodle specifio current differences of up to two orders of magnitude were exhibited indicating that the electrode materlal strongly influsiced the oxygen reduction kinetics.

The electrode bulk and surface effects of a platinum point contact were separated by contaminating the surface with bismuth oxide. The platinum point electrode was held approximately $1 \mathrm{~cm}$ above an alumina crucible containing bismuth oxide. The polarization results of the contaminated platinum electrode are shown in Figure 13 for contamination at $780^{\circ} \mathrm{C}$ and $850^{\circ} \mathrm{C}$, respectively. The solid line in the figure indicates the uncontaminated electrode and is shown for comparison. The variations in the polarization current can be related to changes in the amount of bismuth oxide on the platinum surface. Higher contamination temperatures correspond to the presence of more bismuth oxide. The limiting cathodic current behavior in the bismuth contaminated curve at $850^{\circ} \mathrm{C}$ could not be explained in terms of bismuth oxide affecting the oxygen diffusion rate through the bulk of the electrode material. The bismuth oxide concentration corresponding to these curves was determined to be less than 1.0\% within the first 1.0,000 $\AA$ of platinum surface which was not substantial enough to have an effect on oxygen bulk diffusion. Therefore, an oxygen adsorption model was considered for the bismuth contaminated electrode where the slow reaction was taken to be oxygen adsorption. The overall 
oxygen reduction reaction can be written as:

$$
\begin{aligned}
& \mathrm{O}_{2}(g) \rightarrow 2 \mathrm{O}_{\mathrm{ads}} \\
& \mathrm{O}_{\text {ads }}+2 \mathrm{e} \leftrightarrows \mathrm{o}^{=}
\end{aligned}
$$

where the charge transfer electrochemical step (reaction 2) is rapid and in equilibrium and the adsorption step is rate controlling. Then the current depends on the rate at which oxygen adsorbs and desorbs and can be expressed as:

$$
I=-n F v=-F\left[\begin{array}{llll}
\vec{k} & P_{O_{2}} & S^{2}(1-\theta)^{2}-\overleftarrow{k} S^{2} \theta^{2}
\end{array}\right]
$$

where $v$ is the rate of formation of $O_{\text {ads }}$ and $n$ is the number of electrons transferred in the overall reaction and is equal to 2. $S$ is defined as the total number of sites on which oxygen can absorb, $\theta$ is the fraction occupied, and $\vec{k}$ and $\vec{k}$ are the forward and reverse chemical rate constants respectively. With the assumption that the charge transfer step is in equilibrium, the Nernst equation can be applied to reaction 2 to derive the electrode potential during current flow. The overpotential is then given by:

$$
n_{r}=\frac{R T}{2 F} \ln \frac{\theta(1-\bar{\theta})}{\bar{\theta}(1-\theta)}
$$

where $n_{r}$ is termed the reaction overpotential resulting from the rate limiting adsorption step and $\bar{\theta}$ is the equilibrium or open circuit fractional coverage of $\mathrm{O}_{\text {ads }}$.

Polarization curves have been calculated from Eqs. 3 and 4 and show similar characteristics to the bismuth oxide contaminated curve at $850^{\circ} \mathrm{C}$ in Figure 13 after ohmic polarization corrections. The theoretical and cxperimented Tafel slopes with values of 63.7 $\mathrm{mV}$ and $73 \mathrm{mV}$ are in fair agreement.

The reactions 1 and 2 can also be used to determine the impedance behavior of the interface with reaction 2 as rate controlling. Using an approach similar to Armstrong (7) a parallel $R_{p}-C_{p}$ 
network was modeled. The expressions are as follows:

$$
\mathrm{R}_{\mathrm{p}}=\frac{\left.\frac{\partial \eta_{r}}{\partial \theta}\right|_{\theta_{s}}}{\left.\mathrm{nF} \frac{\partial \mathrm{v}}{\partial \theta}\right|_{\theta_{s}}}
$$

and

$$
c_{p}=\left.\frac{\frac{n F}{\partial \eta_{r}}}{\partial \theta}\right|_{s}
$$

with $\theta_{s}$ equal to the steady state fractional $O_{\text {ads }}$ coverage which is potential dependent and $\mathrm{n}$ is equal to 2 from the overall oxygen reduction. A computer plot in the complex impedance plane of Eqs. 5 and 6 was obtained using Eqs. 3 and 4 as shown in Figure 14. The value of $\bar{\theta}$ was assumed to be 0.1 and all the values of the constants $\vec{k}, \overleftarrow{k}$, and $S$ were taken as unity for simplicity.

The diameters of the arcs along the $R_{S}$ axis in Figure. 14 are equal to the values of $R_{p}$ as given in Eq. 5 and represent the dc resistances associated with the slow oxygen adsorption reaction. The arcs, which get increasingly larger with increasing cathodic potential, are indicative of a cathodic limiting polarization curseill. The value $n f$ the frequency $\left(\omega_{n}\right)$ at the maxillum height of each arc is equal to the reciprocal of the time constant for ad = sorption reaction and is equal to:

$$
\omega_{0}-\frac{1}{\bar{p}_{p} c_{p}}
$$

Exporimental. impedance diagrams are shown in Figure 15 for a platinum paste elertrode containing bismuth oxide. The shirl in the arcs from the origin along the $R_{S}$ axis is caused by the electrolyte resistance. The arcs in Figure 15 are taken to represent the interfacial impedance. A comparison can be made between Figure 15 and the result of the oxygen adsorption model in Figure 14. The experimental results may then be explained in terms of a slow 
oxygen adsorption step when impurities such as bismuth oxide are present.

\subsection{Fuel Electrode Kinetics (E.J.L. Schouler and H. S. Isaacs)}

The noble metals, platinum and gold, are being investigated in detail for oxidation of fuels using dc polarization techniques. Small single contact "ball electrodes" are used in the experimental apparatus described earlier ( 8 ). The polarization of the Pt electrode was studied in different reducing environments including pure argon, $\mathrm{Ar} / \mathrm{H}_{2}, \mathrm{Ar} / \mathrm{H}_{2} / \mathrm{H}_{2} \mathrm{O}, \mathrm{Ar} / \mathrm{H}_{2} \mathrm{O}$ gas mixtures at $1000^{\circ} \mathrm{C}$. The $\mathrm{Ar}$ or $\mathrm{Ar} / \mathrm{H}_{2}$ gases are passed through a water bubbler at a controlled temperature to fix the water vapor pressure. Recondensation of water is avoided by keeping the gas lines at temperatures higher than $100^{\circ} \mathrm{C}$.

The oxygen activity of the gases was measured at $700^{\circ} \mathrm{C}$ using an electrochemical oxygen meter with an air reference, located downstream to the furnace containing the polarization cell. Since the partial pressure ratio of $\mathrm{H}_{2}$ and $\mathrm{H}_{2} \mathrm{O}$ determines the oxygen activity, the emf of the oxygen sensor $\left(E_{S}\right)$ permits an accurate determination of the gas composition from the equation:

$$
E_{S}=E^{\circ}-\frac{R T S}{2 F} \ln \frac{p_{H_{2}}}{p_{H_{2} O}}-\frac{R T}{4 F} \ln 0.21
$$

The reference elcctrode poleitial $\mathrm{E}_{r}$ on the polarization cell operating at a temperature of $\mathrm{T}_{C}$ is related to temperature of the sensor $\left(T_{S}\right)$ by:

$$
E_{r}=-1.247 \frac{T_{C}-T_{S}}{T_{S}}+E_{S} \frac{T_{C}}{T_{S}}
$$

Polarization measurements were made at a scan rate of $5 \mathrm{mV} / \mathrm{s}$. Specific examples of the results obtained are shown in Figures $16 \mathrm{a}$ and $16 \mathrm{~b}$. The potentials are referenced to an air electrode at $1000^{\circ} \mathrm{C}$. In Figure 16a, where only water was added to the argon, 
the open circuit potential was about $-300 \mathrm{mV}$, but not well controlled by the very low level of molecular oxygen in the gas mixture. The anodic currents increased monotonically with potential and were associated with the rate of oxygen evolution given by the reaction:

$$
2 \mathrm{O}_{\mathrm{O}} \rightarrow \mathrm{O}_{2}+2 \mathrm{~V}^{++}+4 \mathrm{e}^{-}
$$

at the single contact platinum electrode. The curvature at the highest anodic current results from resistance polarization. The cathodic curves were a result of the reduction of the impurity nxygen in the gas mixture and the water vapor. 'lhe reduclion rcaction of the water:

$$
\mathrm{H}_{2} \mathrm{O}+\mathrm{V}_{\mathrm{O}}^{++}+2 \mathrm{e}^{-} \rightarrow \mathrm{H}_{2}+\mathrm{O}_{\mathrm{O}}
$$

is associated with a limiting current between the potentials of about -1000 to $-1400 \mathrm{mV}$.

In Figurc 16b, where $\mathrm{H}_{2}$ and $\mathrm{H}_{2} \mathrm{O}$ were present in argon, the open circuit potential was set by the $\mathrm{H}_{2} / \mathrm{H}_{2} \mathrm{O}$ ratio as given by Eq. 8. The anodic portion of the curve is more complex than that in Figure $16 \mathrm{a}$ and is controlled by the oxidation:

$$
2 \mathrm{H}_{2}+\mathrm{O}_{\mathrm{O}} \rightarrow \mathrm{H}_{2} \mathrm{O}+\mathrm{V}_{\mathrm{o}}^{++}+2 \mathrm{e}^{-}
$$

between about $-750 \mathrm{mV}$ and $0 \mathrm{mV}$ and by oxygen evolution above this potential. Between -400 and $0 \mathrm{mV}$, there is again a limiting current. It is associated with the oxidation of the hydrogen. The cathodic portion of the curve is similar to the results in Figure 16a. The increase in cathodic current at the most negative potentials is associated with reduction of lite electrolyta by the injection of electrons as opposed to water reduction. In all measurements, some hysteresit in the currents was observed.

The lack of agreement between cathodic curves at low potentials in Figures $16 \mathrm{a}$ and $16 \mathrm{~b}$ was possibly a result of the poorly controlled referencc electrote when the cathodic results in Figure 16 a were obtained. 
The curves in Figure 17 show the results of a series of polarization measurements for a constant $\mathrm{H}_{2} \mathrm{O}$ and a variable $\mathrm{H}_{2}$ con- . centration with a platinum single contact electrode. As the hydrogen concentration was increased, the open circuit potential decreased in accordance with Eqs. 8 and 9. The limiting currents for the hydrogen oxidation reaction at $-300 \mathrm{mV}$ increased with increased hydrogen concentration. The oxygen evolution current at the more positive potentials remained constant within experimental error and was not influenced significantly by the presence of increased concentrations of hydrogen. Similarly, the limiting current of the water reduction reaction at $-1200 \mathrm{mV}$ was not changed by increasing the hydrogen concentration. The reproducible maximum at $-1400 \mathrm{mV}$ was associated with a redox type reaction but has not been identified.

Results in Figure 18 for the variation of the limiting current for hydrogen oxidation as a function of hydrogen concentration were obtained from Figure 17 and similar curves. The unity slope in Figure 18 shows a direct proportionality between hydrogen concentration and the limiting current. In related work on the reduction of water, the limiting current was found to be proportional to the square root of the water concentration.

The influence of water concentration on the kinetics of the hydrogen ionization reaction was also investigated in a fixed $\mathrm{H}_{2} /$ Ar gas concentration. The limiting current for hydrogen oxidation decreased with increased water concentrations which is caused by either a kinetic limitation or a simple dilution of the llyarogen (and argon) resulting from the increased quantities of steam. In accord with a dilution effect, the $\mathrm{H}_{2}$ partial pressure is related to water concentration by:

$$
\mathrm{p}_{\mathrm{H}_{2}}{ }^{-1}=\left(1-\frac{1}{\mathrm{c}}\right)+\frac{\mathrm{p}_{\mathrm{H}_{2} \mathrm{O}}}{\mathrm{p}_{\mathrm{H}_{2}}}
$$

where $\mathrm{p}_{\mathrm{H}_{2}} \mathrm{O} / \mathrm{P}_{\mathrm{H}_{2}}$ is obtained from the oxygen meter readings (Eq. 8) 
and $\mathrm{c}$ is the initial concentration of $\mathrm{H}_{2}$ in argon. A plot of the limiting hydrogen current versus the $\mathrm{H}_{2} / \mathrm{H}_{2} \mathrm{O}$ ratio (Figure 19) yields supporting evidence for the dilution effect.

Measurements are being conducted on $\mathrm{Au}$ electrodes at the present time and will be presented in the next quarterly report. 
REFERENCES

1. P. Stonehart, J. McDonald, V. Jalan and J. Baris, National Fuel Cell Seminar Abstracts, Bethesda, Maryland, June 26-28, 1979 ; pp. 102-5.

2. G. A. Gruver, W. H. Steuernagel and H. R. Kunz, Extended Abstracts, Fall Meeting of the Electrochemical Society, Los Angeles, California, October 14-19, 1979, The Flectrochemical Society, Inc., Princeton, New Jersey, Vol. 79-2, Abstract No. 189.

3. A. O. Isenberg, Extended Abstracts, Spring Meeting of the Electrochemical Society, Philadephia, Pennsylvania, May 8-13, 1977. The Electrochemical Society, Inc., Vol. 77-1, Abstract No. 394 .

4. H. S. Isaacs and L. J. Olmer, Proceedings of Workshop on High Temperature Solid Oxide Fuel Cells, Brookhaven National Laboratory, Upton, New York, May 5-6, 1977, p. 153 (BNI, 50756).

5. S. Pizzini, Fast Ion Transport in Solids, Van Gool (Ed.), N. Holland/Amer. Elsevier, 1973, p. 461.

6. J. Newman, J. Electrochem. Soc. 117, 198 (1970).

7. R. D. Armstrong, R. E. Firman and H. R. Thirsk, Disc. Faraday Soc. $56, ' 244$ (1973).

8. S. Srinivasan, H. S. Isaacs, J. McBreen, W. E. O'Grady, H. Olender, L. J. Olmer, E.J.L. Schouler and R. R. Adzic, Fuel Cell Applied Research: Electrocatalysis and Materials, Quarterly Report, July 1. - September 30, 1979, Brookhaven Nationdl Laboratory, Upton, New York, 1979, p. 22 (BNL 51198/FC-8). 


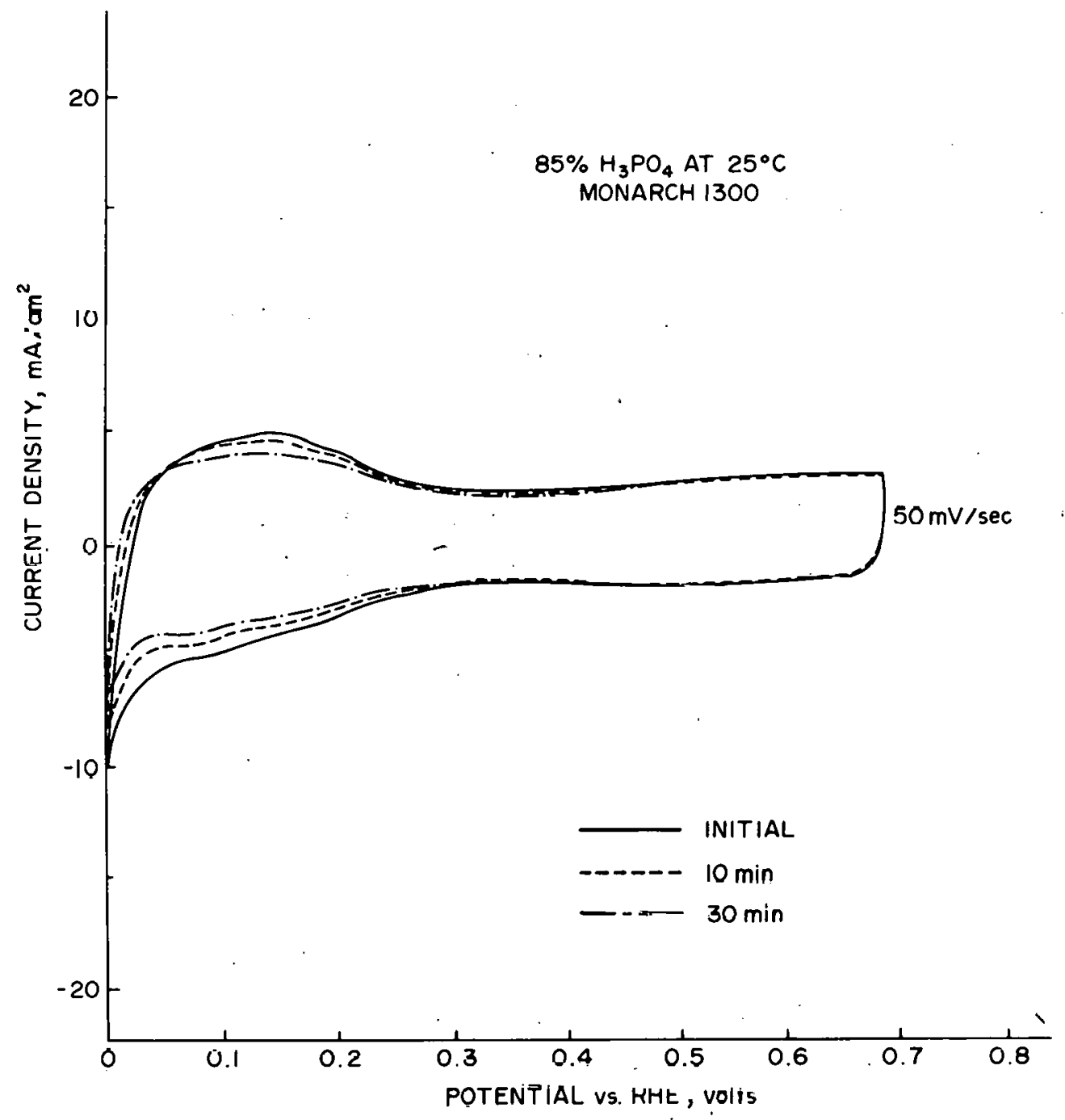

Fiyuie la. Gyelin Voltammogram on Monarch 1300 Supported Platinum Electroce in $85 \% \mathrm{H}_{3} \mathrm{PU}_{4}$ at $25^{\circ} \mathrm{C}$. 


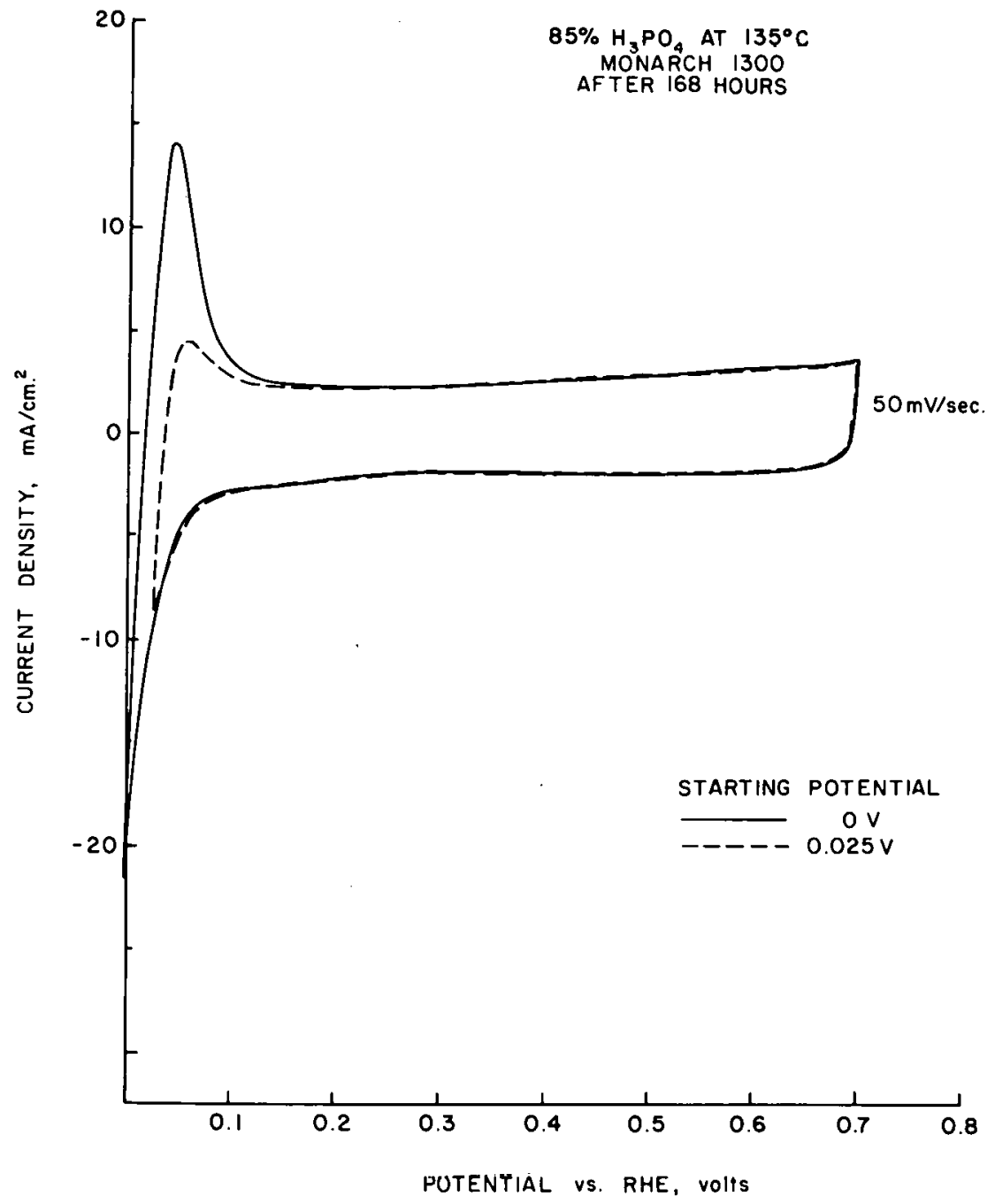

Figure 1b. Cyclic Voltammogram on Monarch 1300 Supported Platinum Electrode in $858 \mathrm{H}_{3} \mathrm{PO}_{4}$ at $135^{\circ} \mathrm{C}$ After $168 \mathrm{~h}$. 


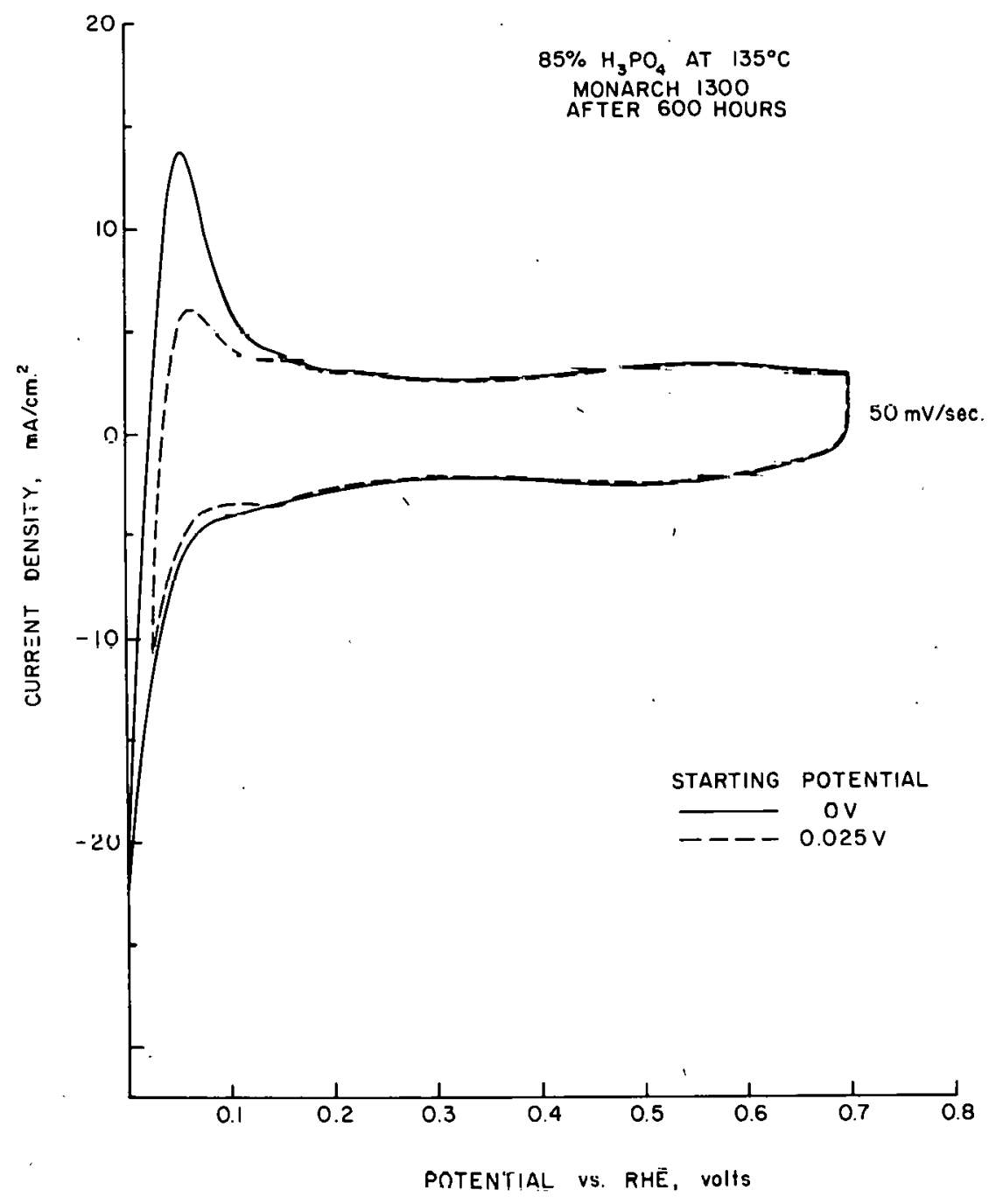

Figure 1c. Cyclic Vol.tammogram on Monarch 1300 Supported Platinum Electrode in $85 \% \mathrm{H}_{3} \mathrm{PO}_{4}$ at $135 \circ$ C After $600 \mathrm{~h}$. 


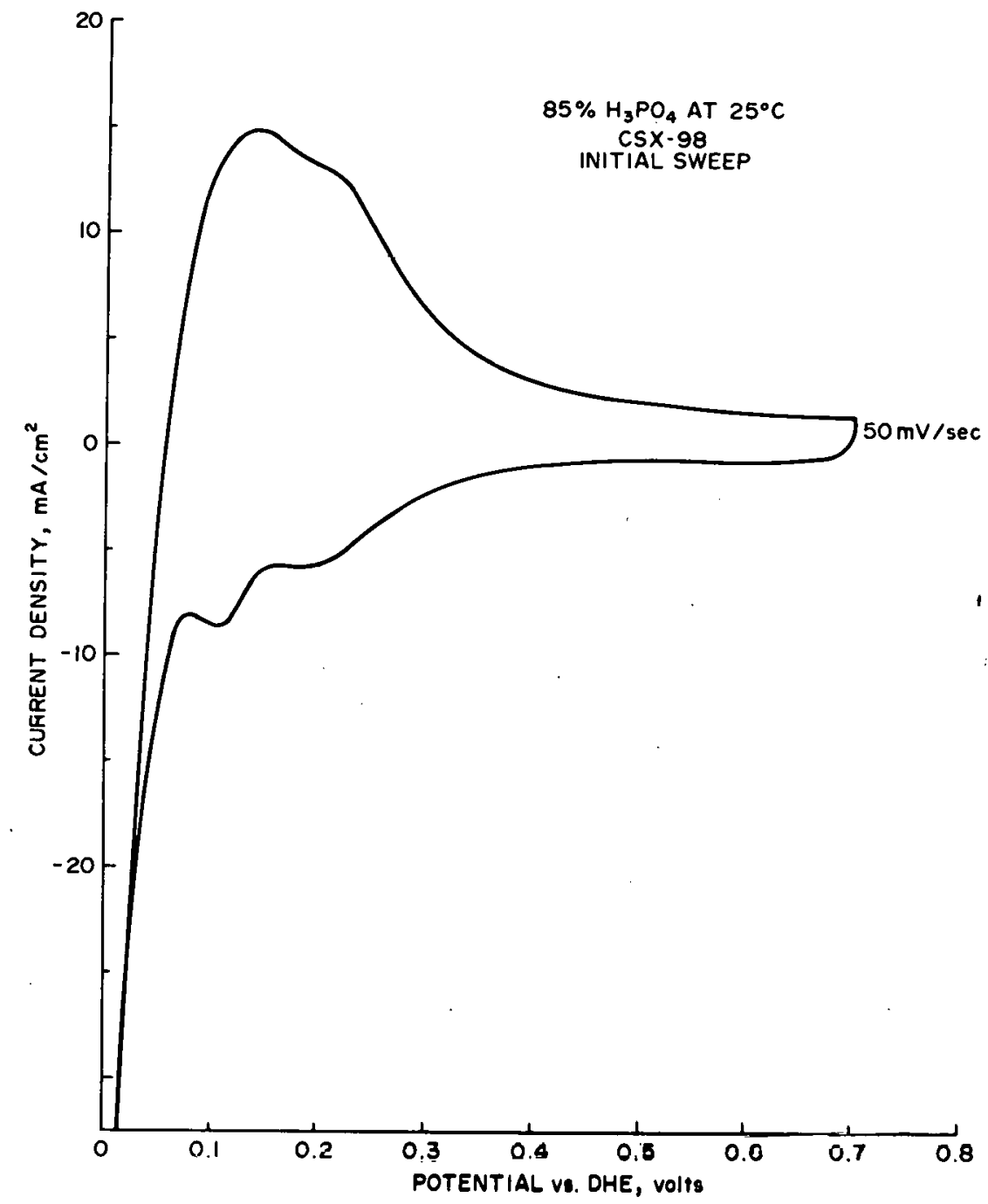

Figure 2a. Cyclic Voltammogram on $\operatorname{csx} 98$ Supported Platinum Electrode in $85 \frac{\circ}{\circ} \mathrm{H}_{3} \mathrm{PO}_{4}$ at $25^{\circ} \mathrm{C}$ Initially. 


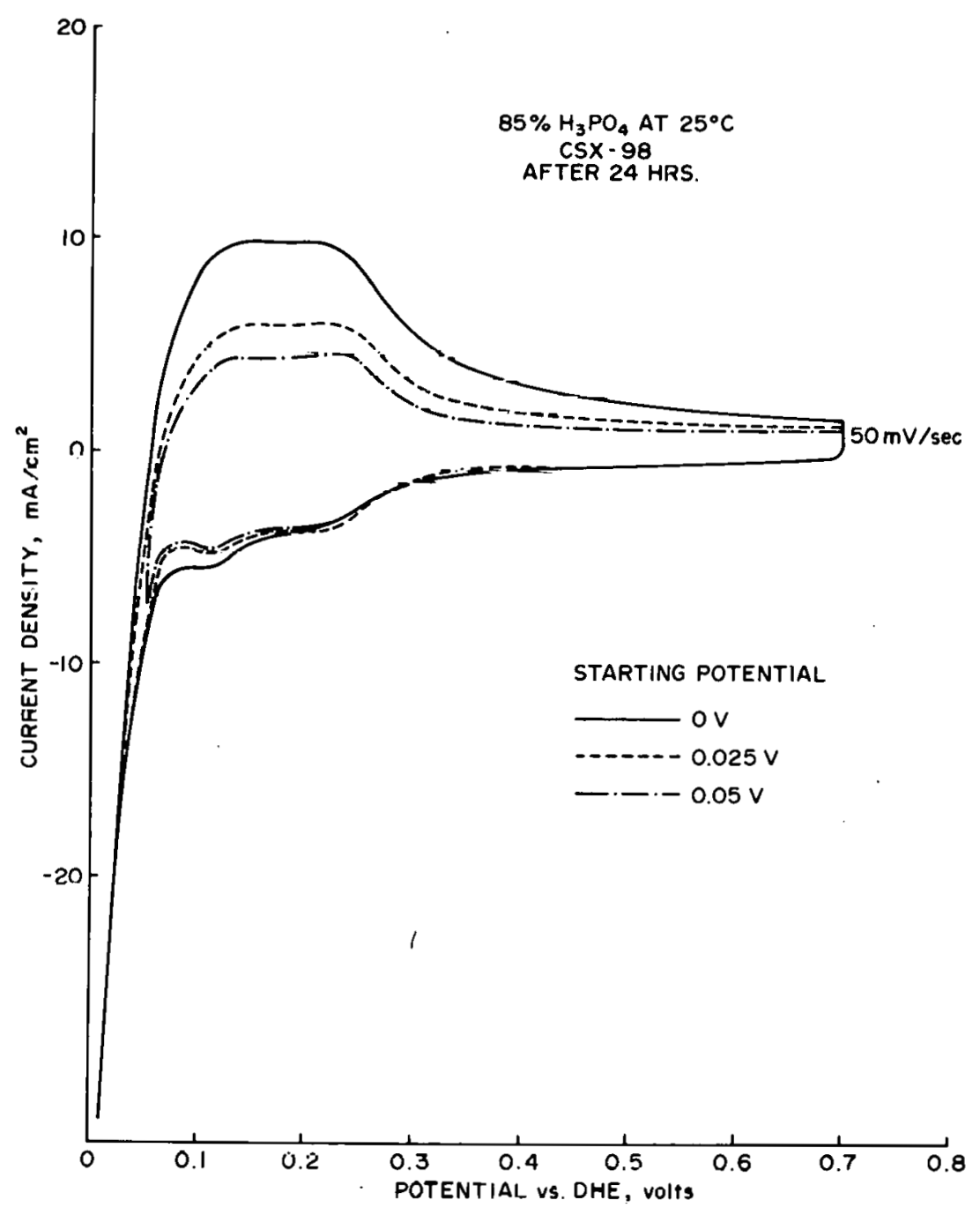

Figure 2b. Cyclic Voltammogram on CSx 98 supported Platinum Flectrode in $858 \mathrm{H}_{3} \mathrm{PO}_{4}$ at $25^{\circ} \mathrm{C}$ After $24 \mathrm{~h}$. 


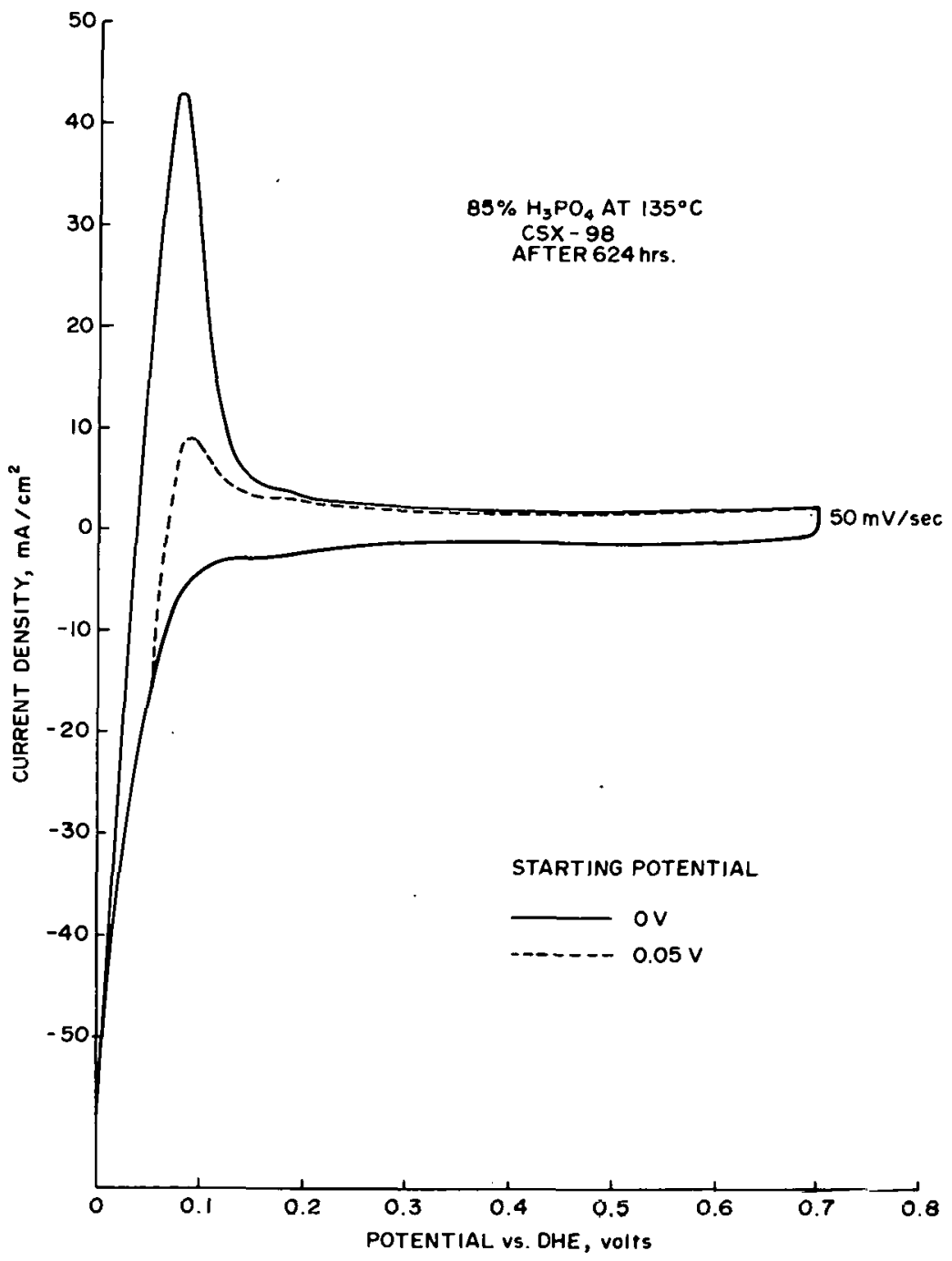

Figure 2c. Cyclic Voltammogram on CSX 98 Supported Platinum Electrode in $85 \% \mathrm{H}_{3} \mathrm{PO}_{4}$ at $135^{\circ} \mathrm{C}$ After $624 \mathrm{~h}$. 


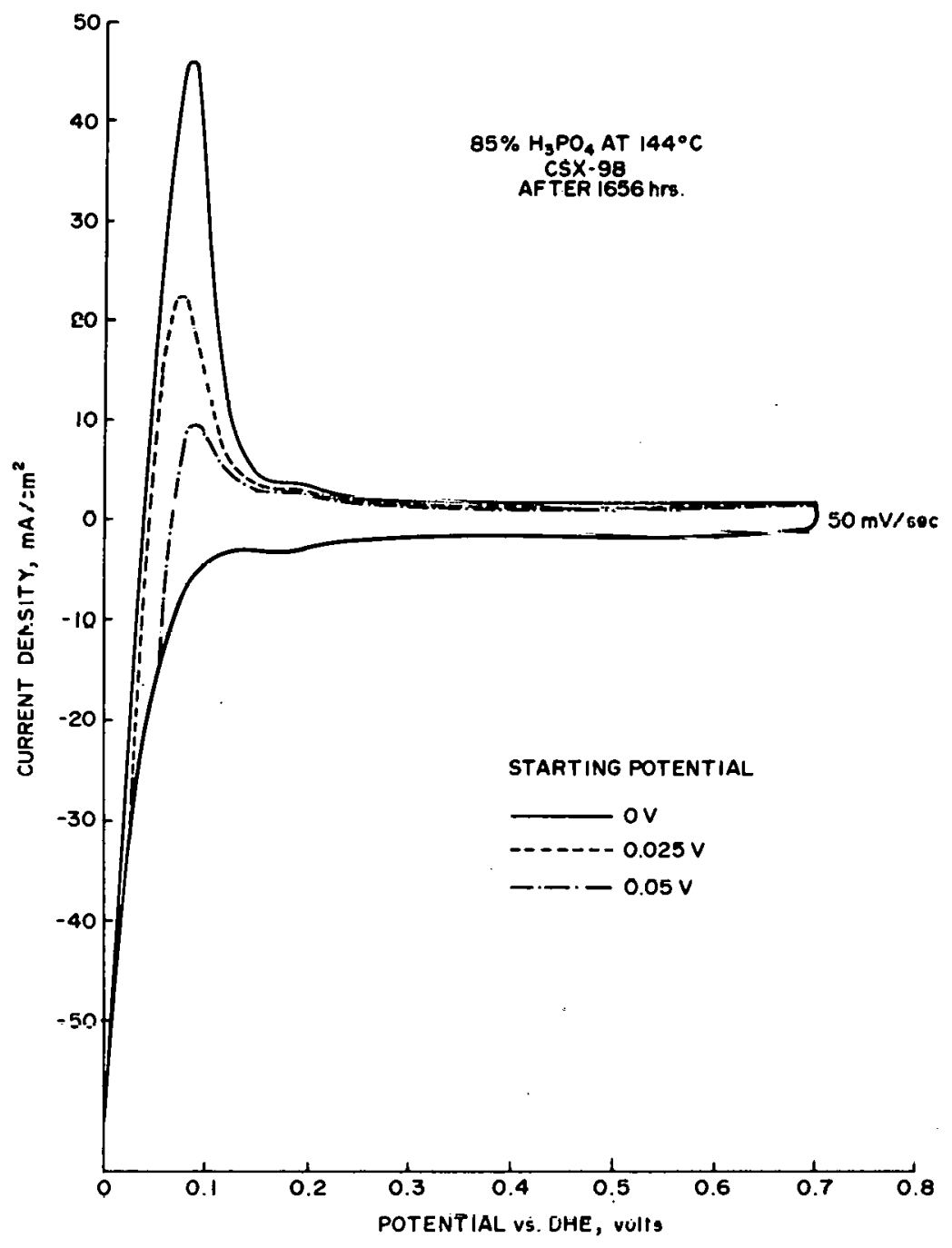

Figure 2d. Cyclic Voltammogram on CSX 98 Supported Flatinum F.lertrode in $858 \mathrm{H}_{3} \mathrm{PO}_{4}$ at $135^{\circ} \mathrm{C}$ After $1656 \mathrm{~h}$. 


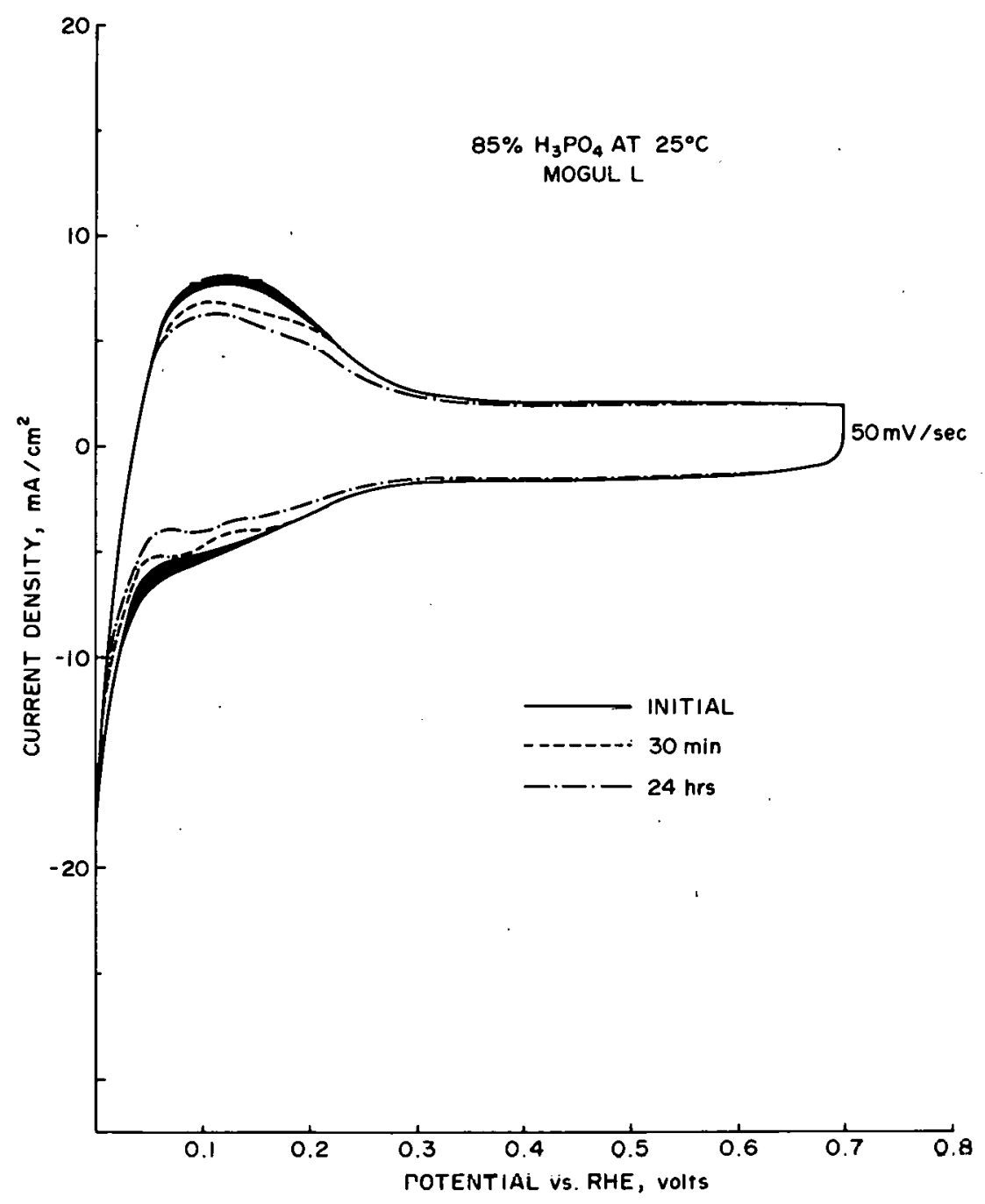

Figure 3a. Cyclic Voltammogram on Mogul L Supported Platinum Electrode in $85 \% \mathrm{H}_{3} \mathrm{PO}_{4}$ at $25^{\circ} \mathrm{C}$. 


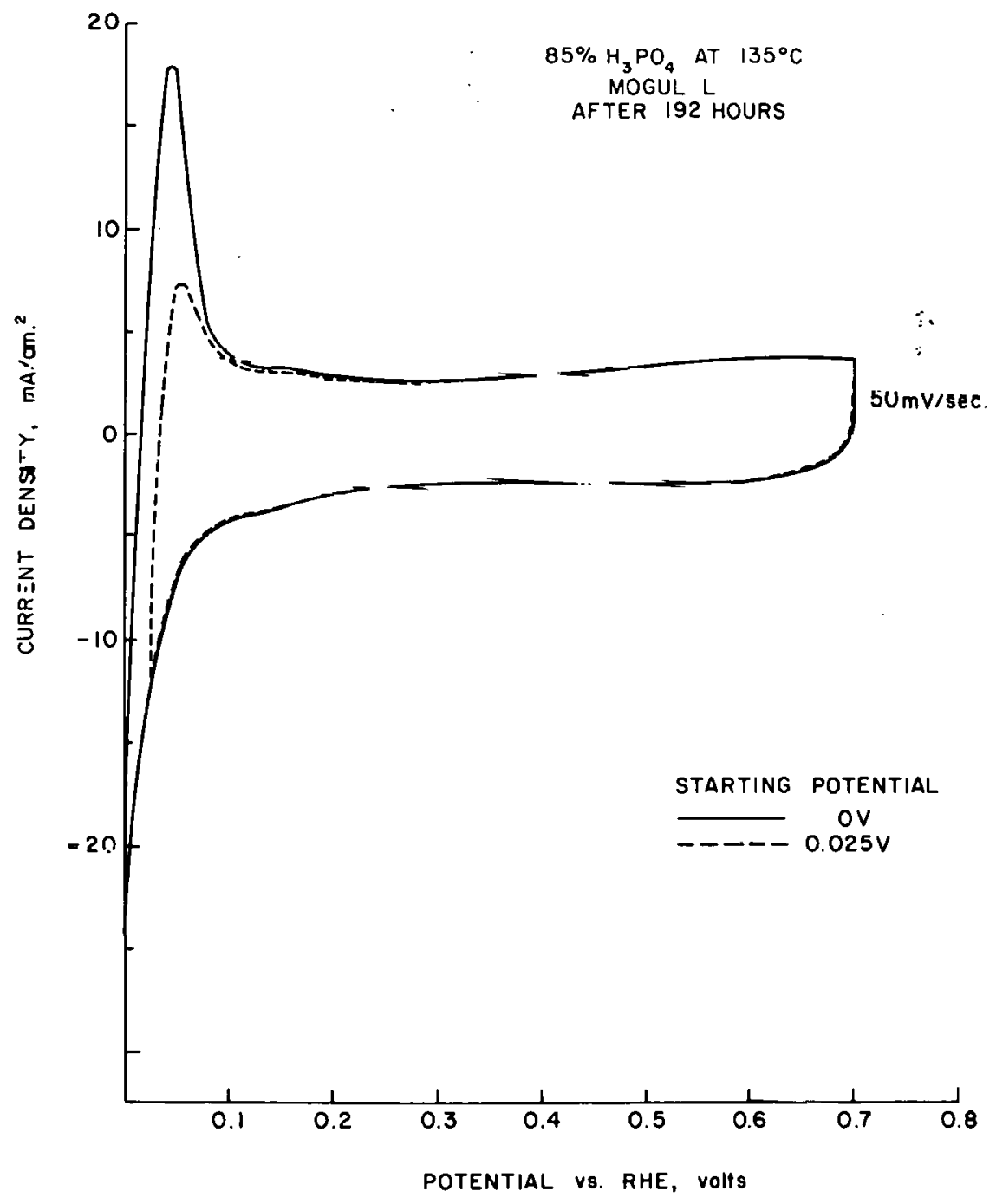

Figure 3b. Cyclic Voltammogram on Mogul T. Supported Platinum E.lectrode in $858 \mathrm{H}_{3} \mathrm{PO}_{4}$ at $135^{\circ} \mathrm{C}$ After $192 \mathrm{~h}$. 


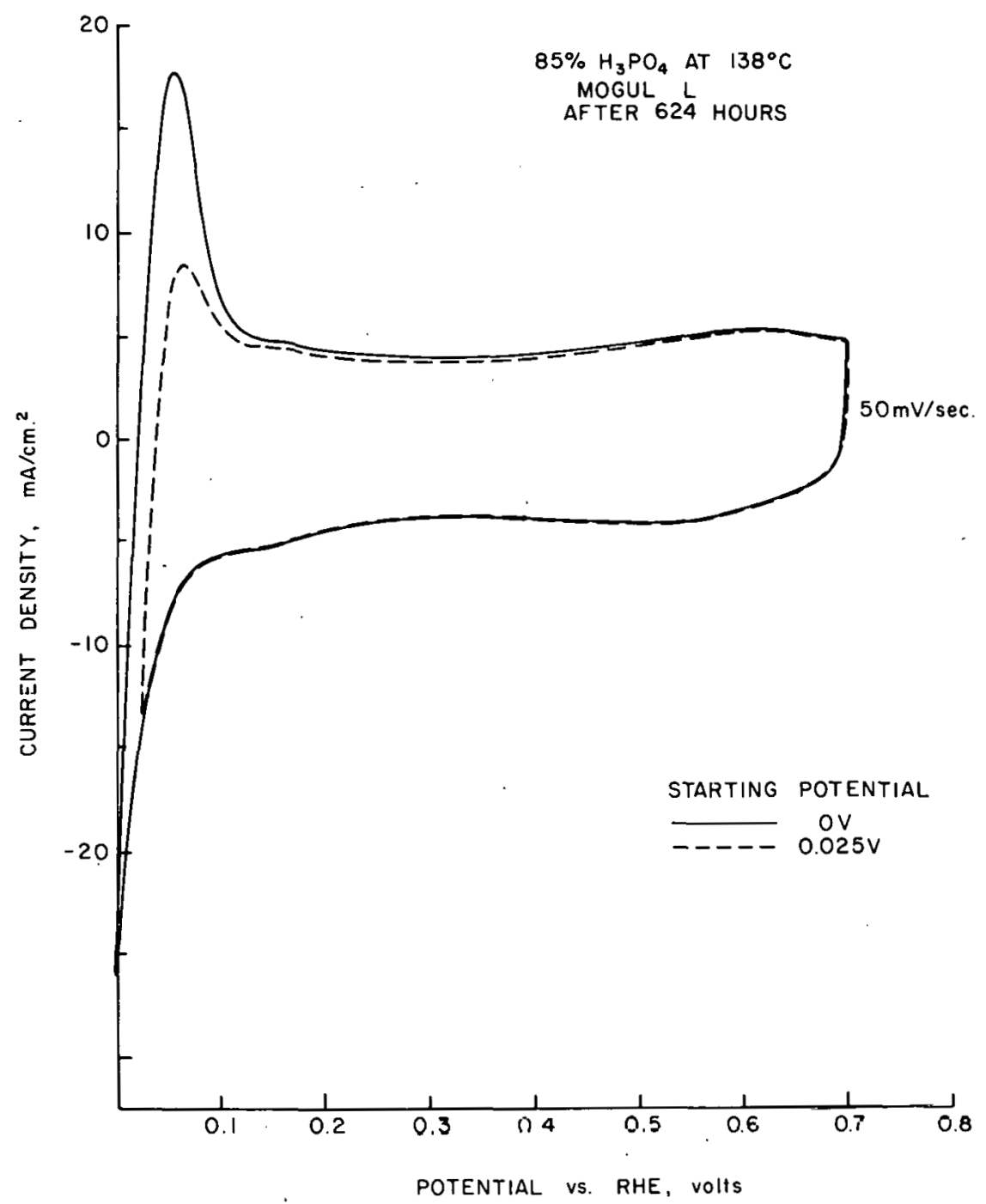

Figure 3c. Cyclic Voltammogram on Mogul L Supported Platinum Electrode in $858 \mathrm{H}_{3} \mathrm{PO}_{4}$ at $138^{\circ} \mathrm{C}$. After $624 \mathrm{~h}$. 


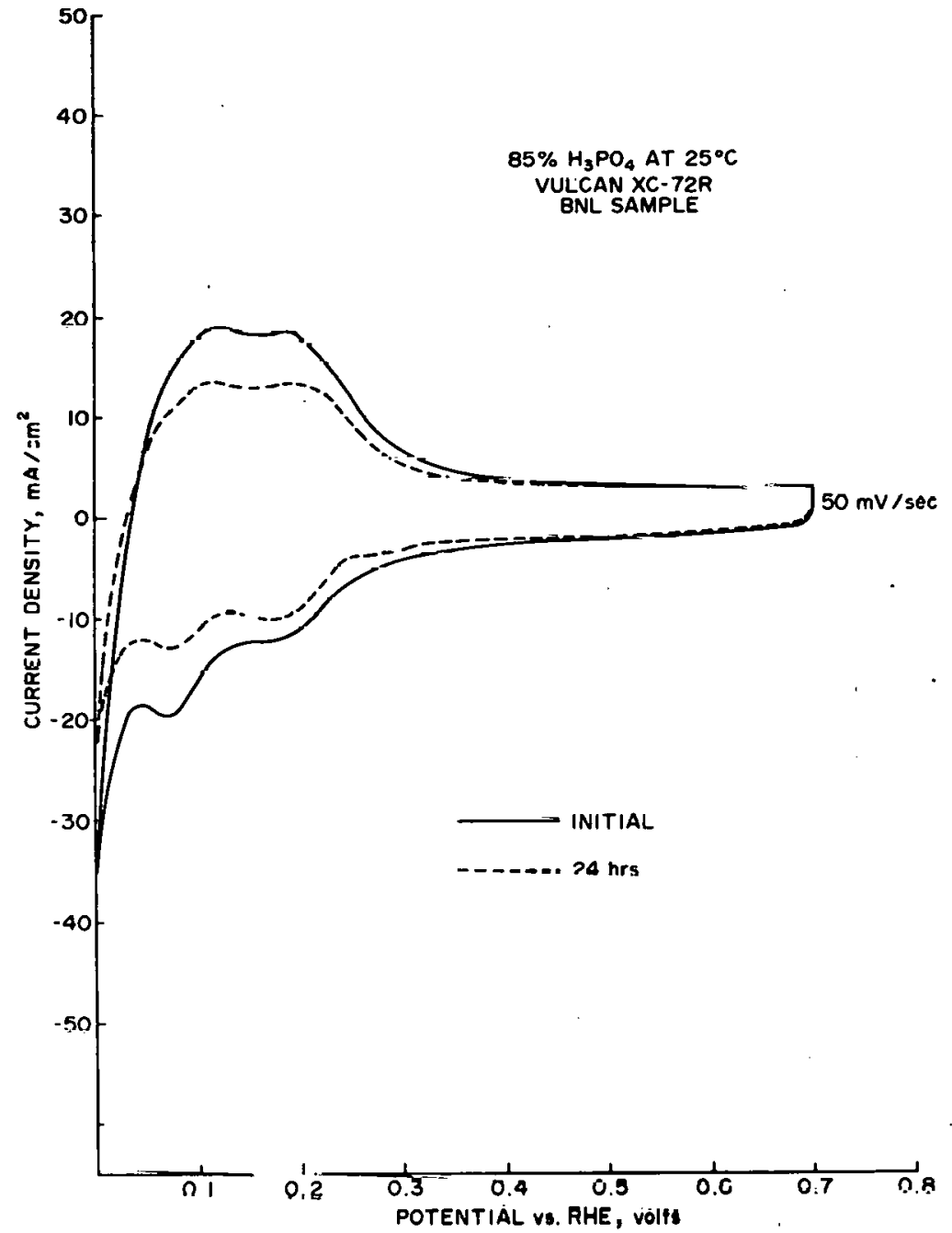

l'igure 4a. Cycliic Vol.tammogram on BNL Prepared Vulcan $\mathrm{XC}-72 \mathrm{R}$ Supported Platinum Electrode in $85 \% \mathrm{H}_{3} \mathrm{PO}_{4}$ at $25^{\circ} \mathrm{C}$. 


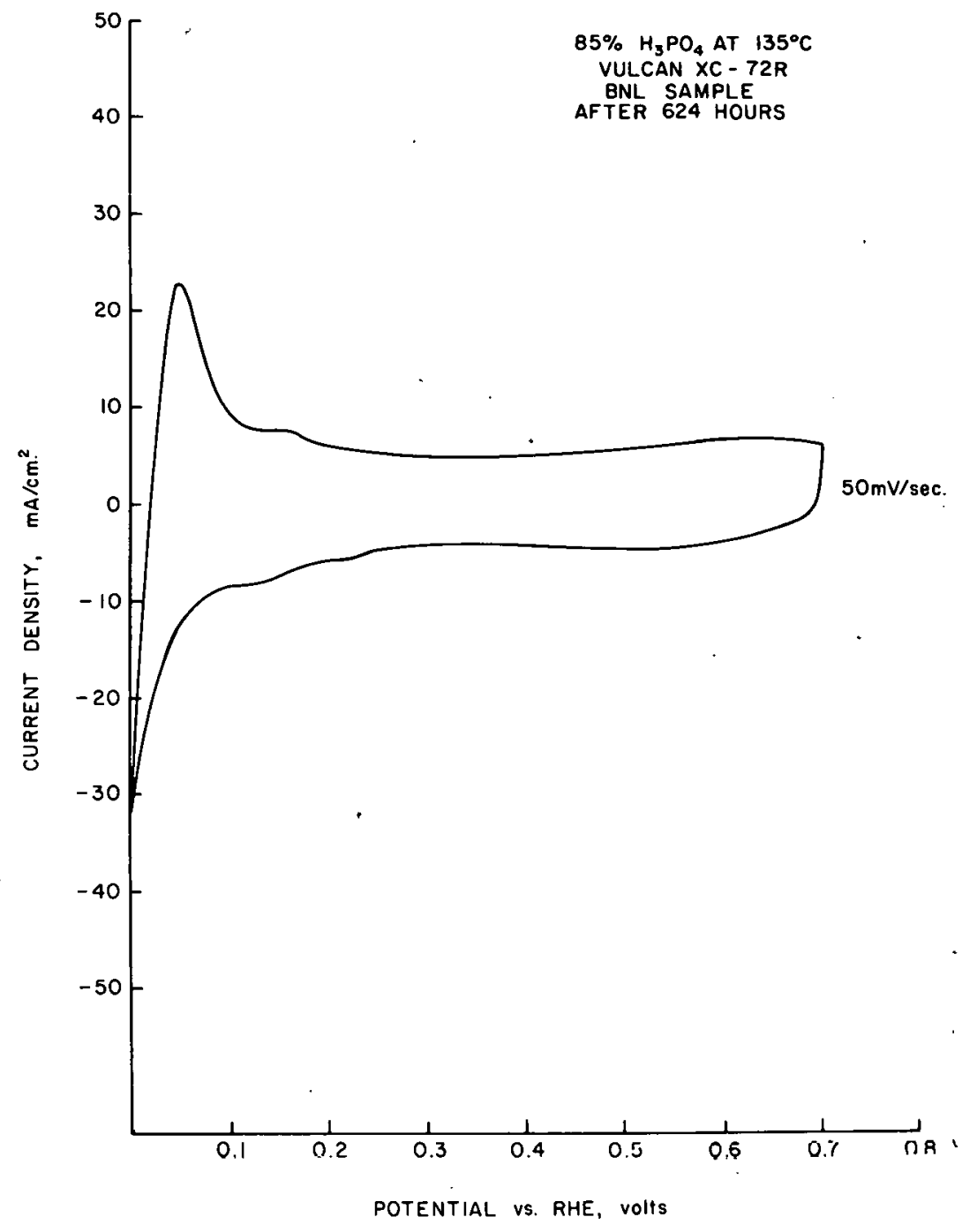

Figure 4b. Cyclic Voltammogram on BNL Prepared Vulcan $\mathrm{XC}-72 \mathrm{R}$ Supported Platinum Electrode in $85 \% \mathrm{H}_{3} \mathrm{PO}_{4}$ at $135^{\circ} \mathrm{C}$ After $624 \mathrm{~h}$. 


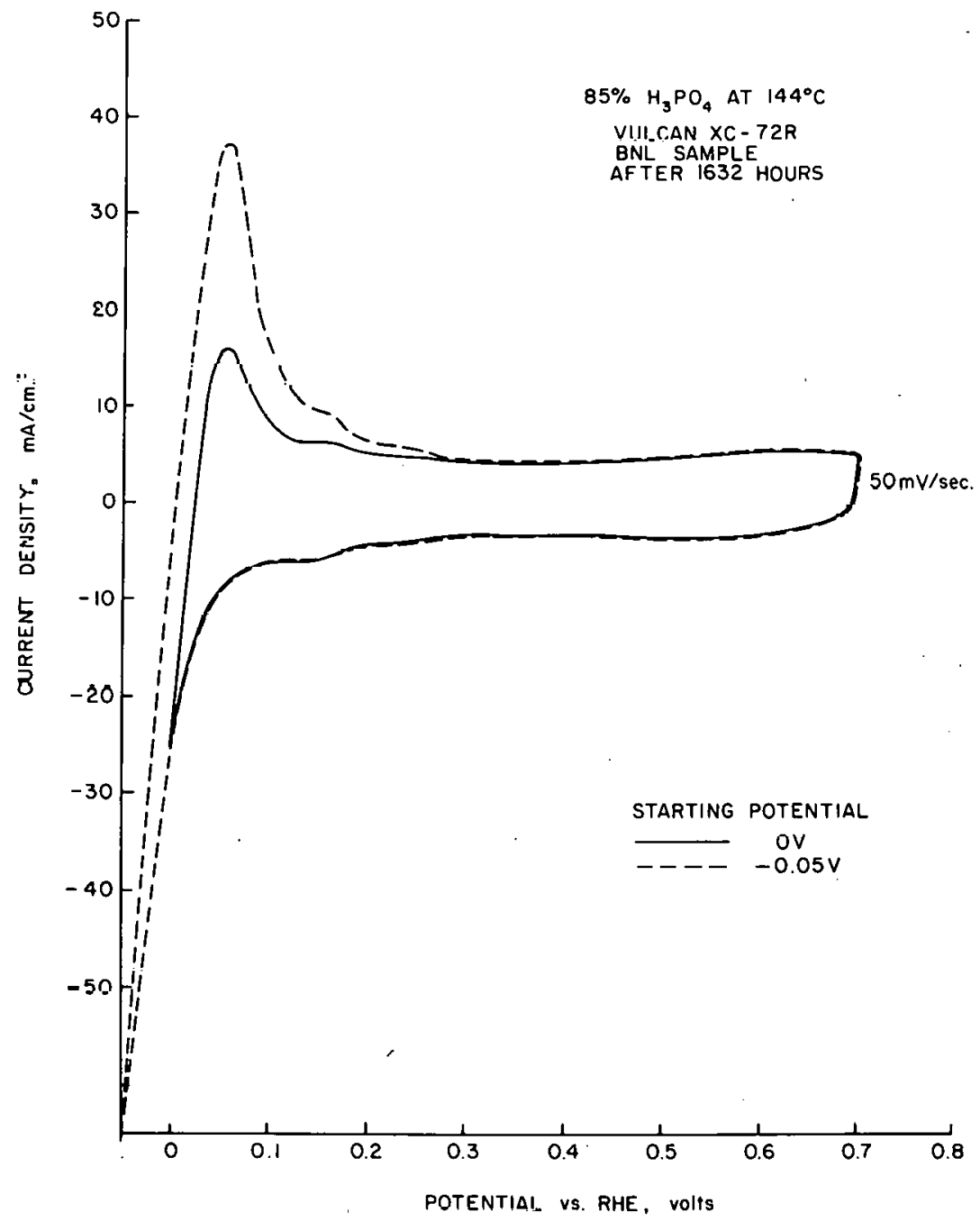

Figure $4 \mathrm{c}$. Cyclic Voltammogram on BNL Prepared Vulcan $\mathrm{XC}-72 \mathrm{R}$ supported Ilitinum Electrodc in $85 \% \mathrm{H}_{3} \mathrm{PO}_{4}$ at $144 \mathrm{C}$ After $1632 \mathrm{~h}$. 


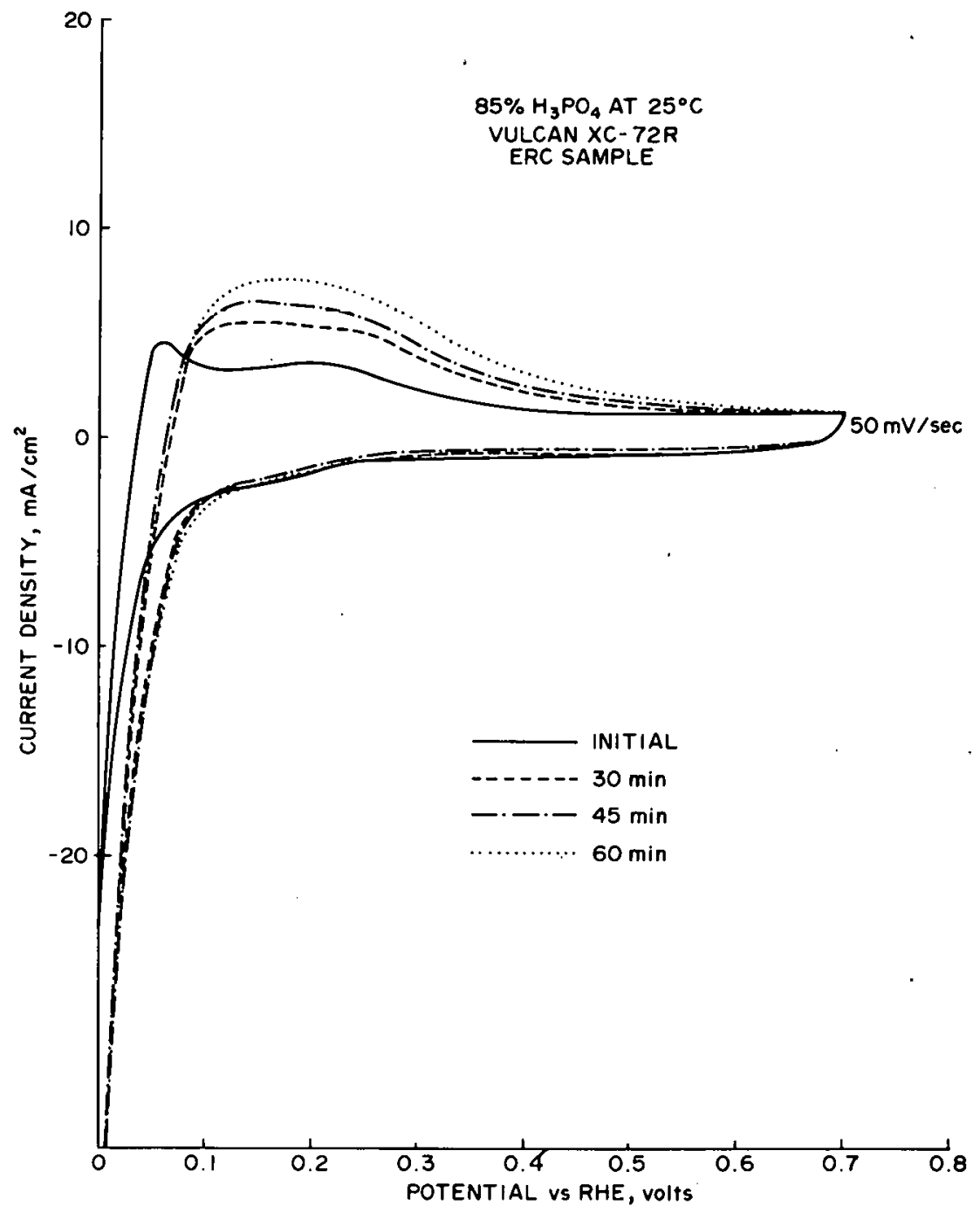

Figure 5a. Cyclic Voltammogram on FRC Prepared Vulcan XC-72R Supported Platinum Electrode in $85 \% \mathrm{H}_{3} \mathrm{PO}_{4}$ at $25^{\circ} \mathrm{C}$. 


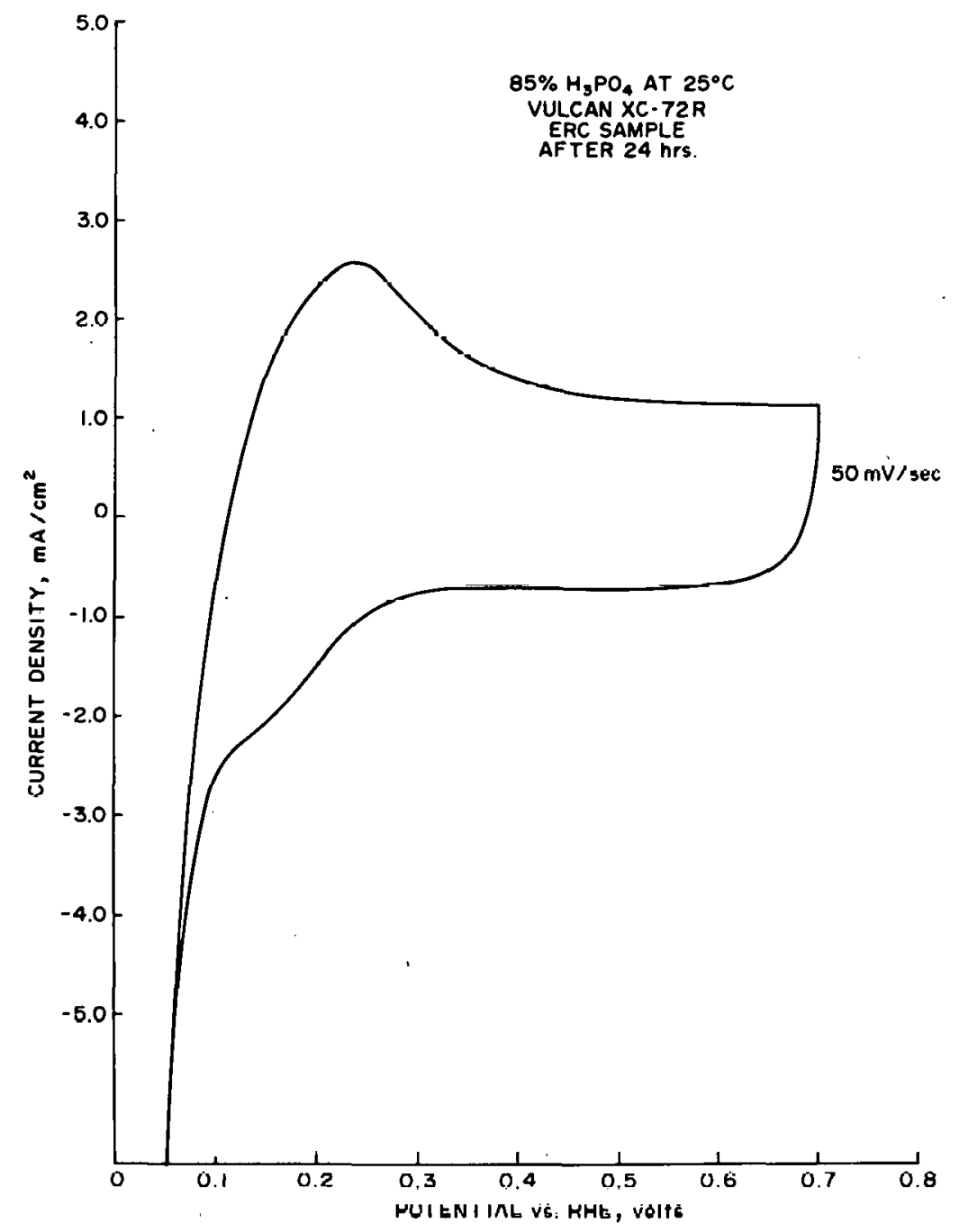

Figure 5b. Cyclic Voltammogram on ERC prepared Vulcan $\mathrm{XC}-72 \mathrm{R}$ Supported Platinum Electrode in $858 \mathrm{H}_{3} \mathrm{PO}_{4}$ at $25^{\circ} \mathrm{C}$ After $21 \mathrm{~h}$. 


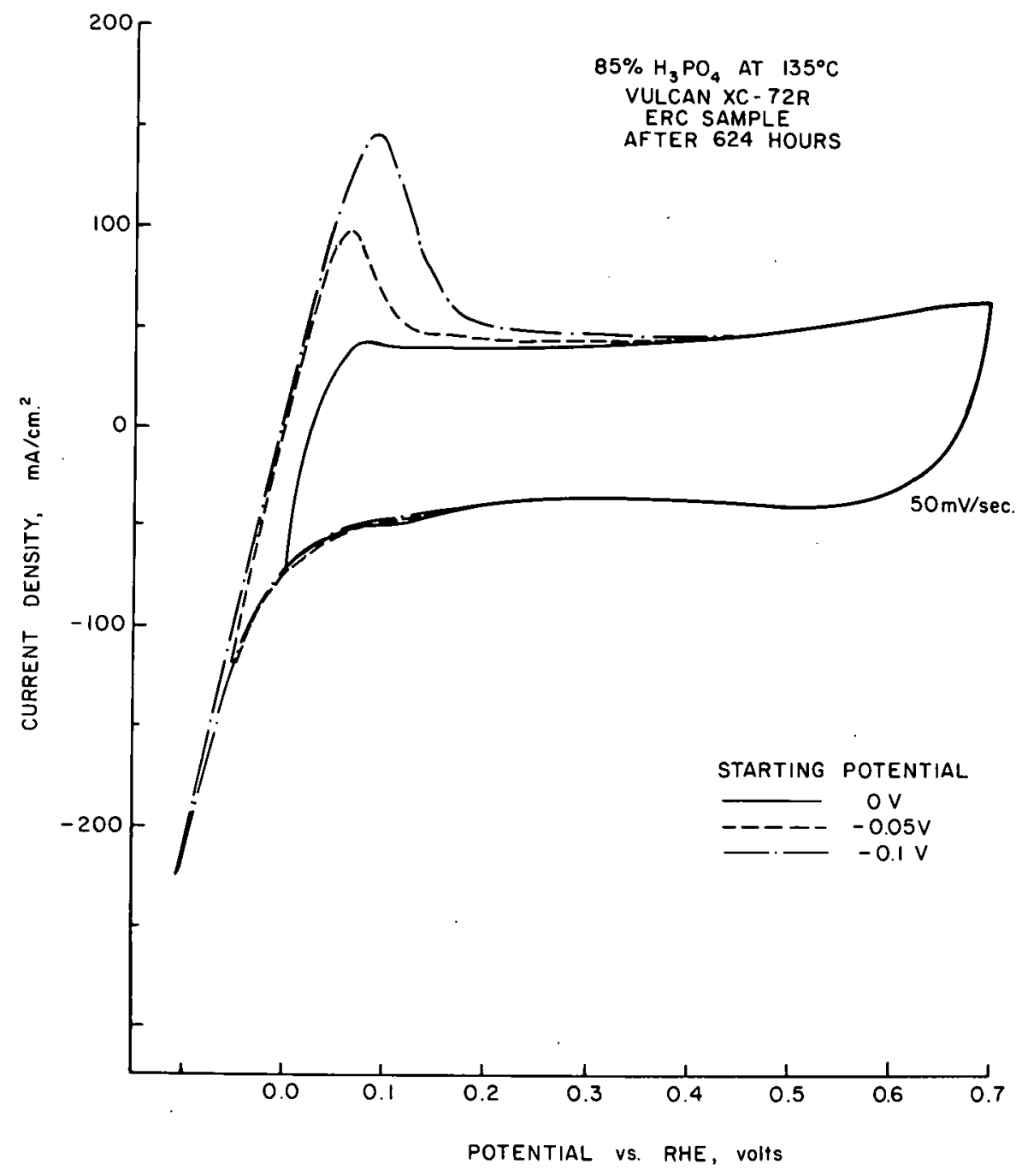

Figure 5c. Cyclic Voltammogram on E.RC Prepared Vulcan XC-72R Supported Platinum Electrode in $85 \% \mathrm{H}_{3} \mathrm{PO}_{4}$ at $135^{\circ} \mathrm{C}$ After $624 \mathrm{~h}$. 


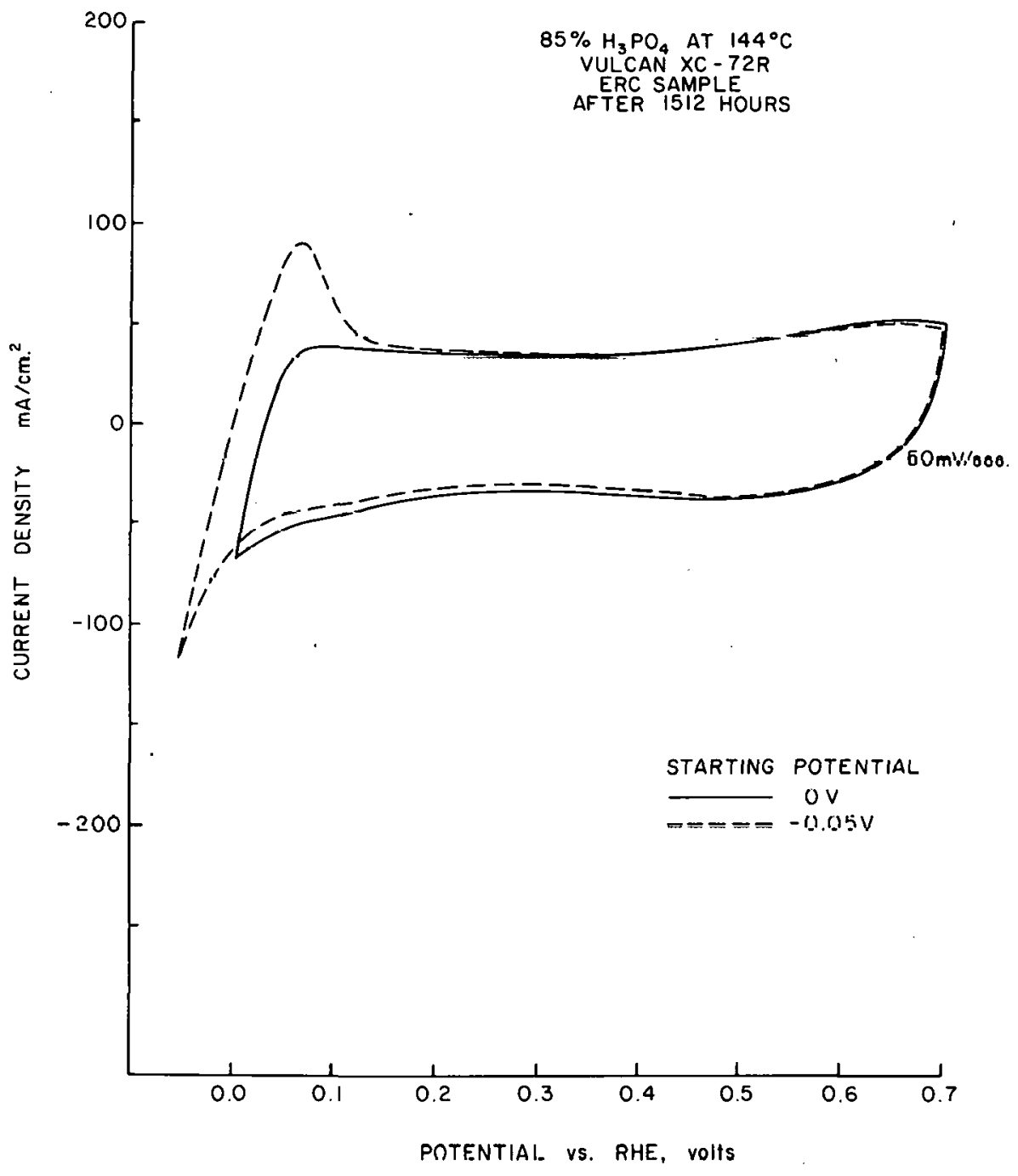

Flgute 5d. Cyolic voltärnogram on LRC prepared Vulcan XC-72R Supported Platinum Electrode in $85 \% \mathrm{H}_{3} \mathrm{PO}_{4}$ at $144^{\circ} \mathrm{C}$ After $1512 \mathrm{~h}$. 


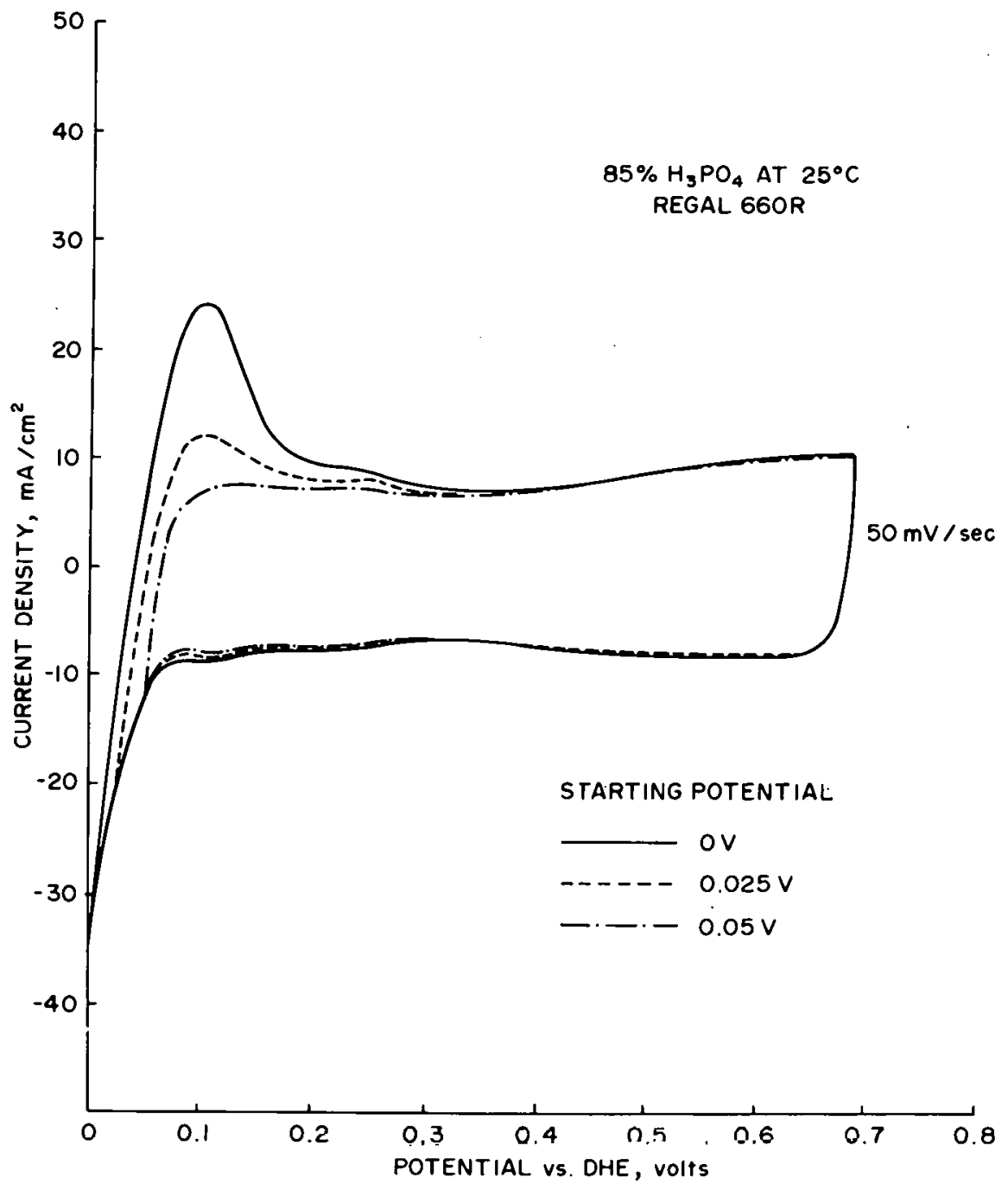

Figure 6a. Cyclic Voltammogram on Regal 660R Supported Platinum Electrode in $858 \mathrm{H}_{3} \mathrm{PO}_{4}$ at $25^{\circ} \mathrm{C}$. 


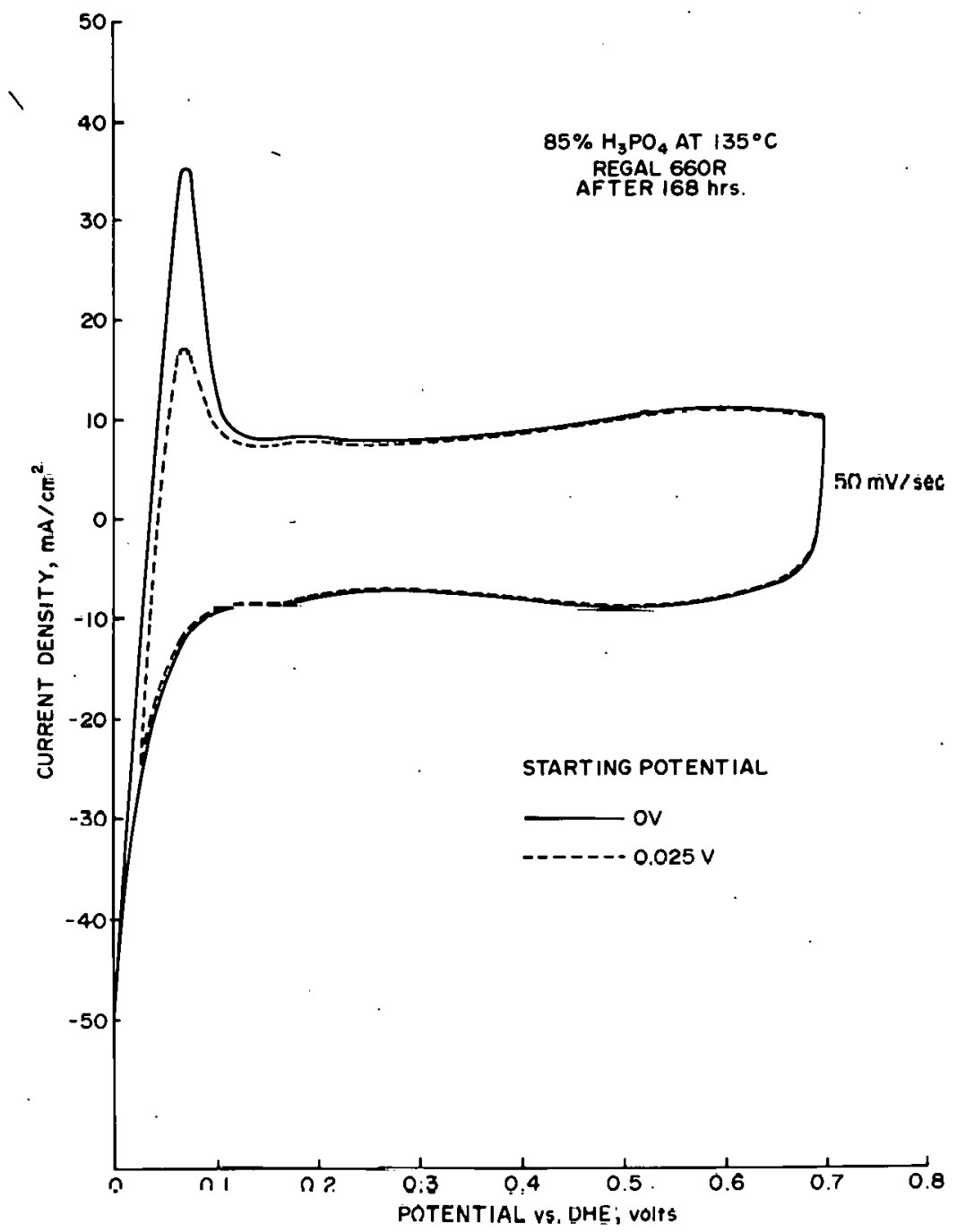

Figure 6b. Cyclic vol tammogram on Regal $660 \mathrm{R}$ Supported Platinum Electrode in $85 \% \mathrm{H}_{3} \mathrm{PO}_{4}$ at $1350 \mathrm{C}$ After $168 \mathrm{~h}$. 


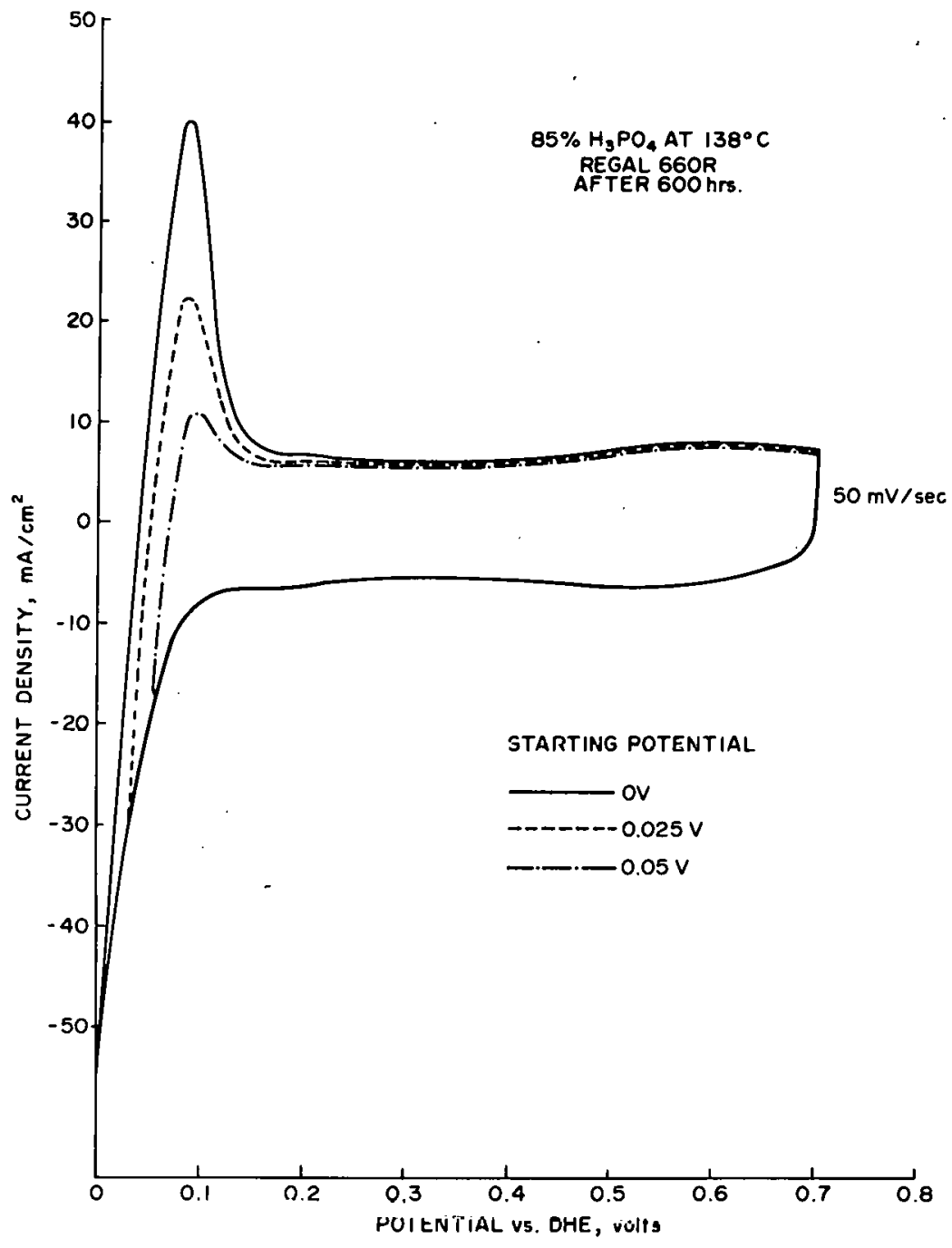

Figure 6c. Cyclic Voltammogram on Regal 660R Supported Platinum Electrode in $85 \% \mathrm{H}_{3} \mathrm{PO}_{4}$ at $138^{\circ} \mathrm{C}$ After $600 \mathrm{~h}$. 


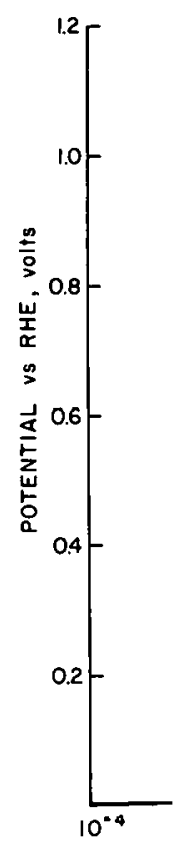

A
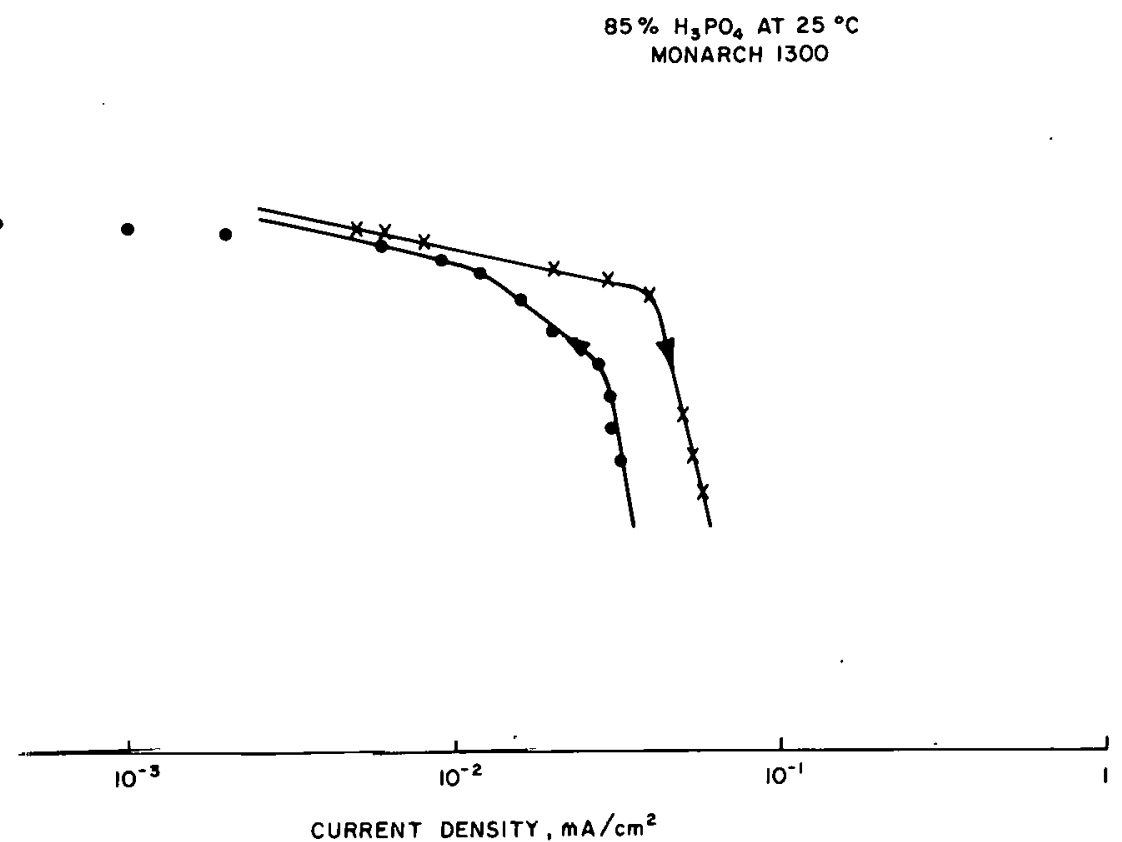

.

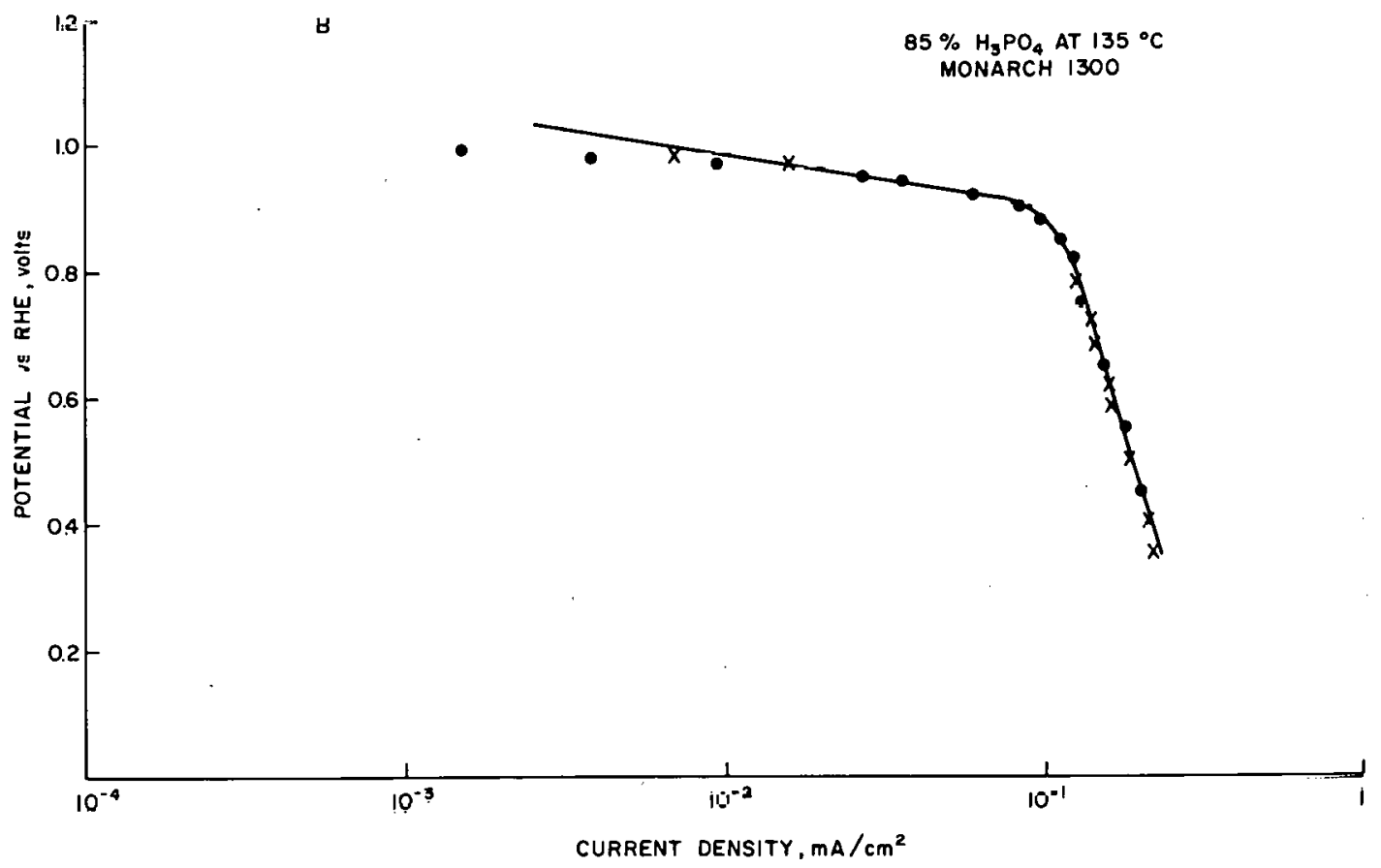

Figure 7. Current-Potential Behavior for oxygen Reduction on Monarch 1300 Supported Platinum Electrode in $85 \% \mathrm{H}_{3} \mathrm{PO}_{4}$ at (a) $25 \circ \mathrm{C}$ (Arruws Indicate Increasing on Decreasing Current) and (b) $135^{\circ} \mathrm{C}$. 

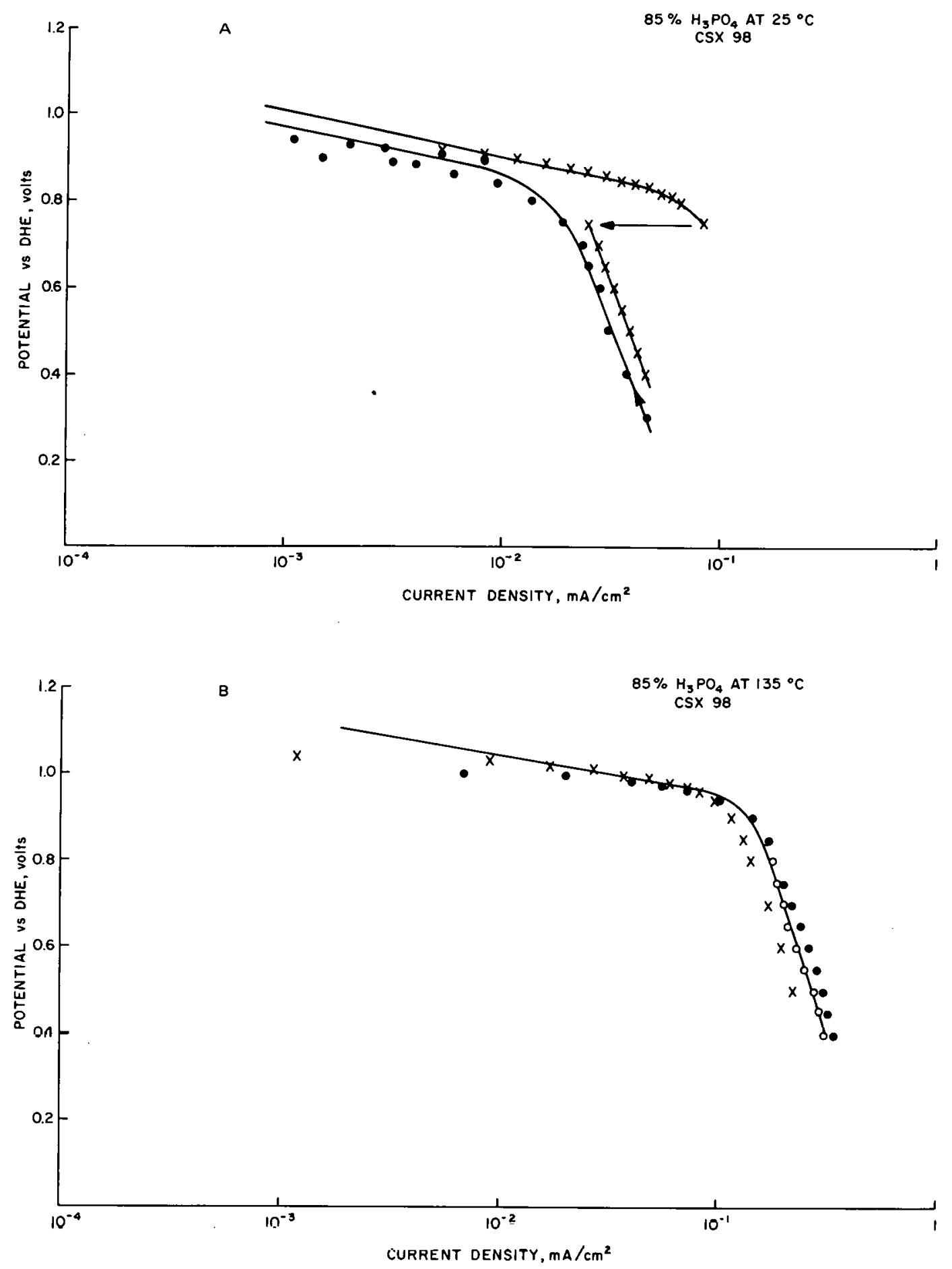

Figure 8. Current-Potential Behavior for Oxygen Reduction on CSX 98 Supported Platinum Electrode in $85 \% \mathrm{H}_{3} \mathrm{PO}_{4}$ at (a) $25^{\circ} \mathrm{C}$ (Arrows Indicate Hysteresis) and (b) $135^{\circ} \mathrm{C}$. 


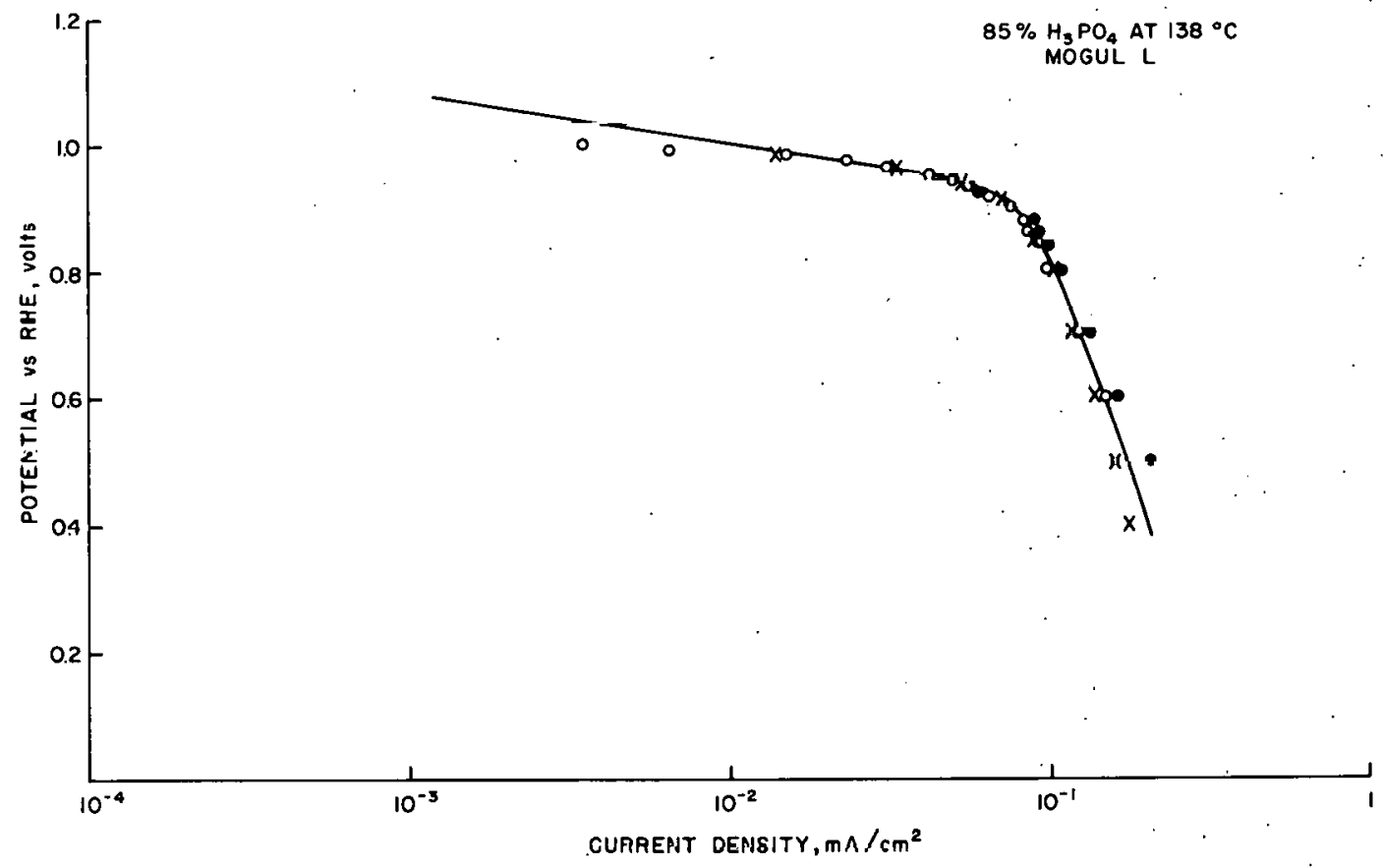

Pigure: 0. Curront-Potential Rohavinr for nxygen. Reduction on Mogul L Supported Platinum Electrode in $85 \% \mathrm{H}_{3} \mathrm{PO}_{4}$ at $138^{\circ} \mathrm{C}$. 

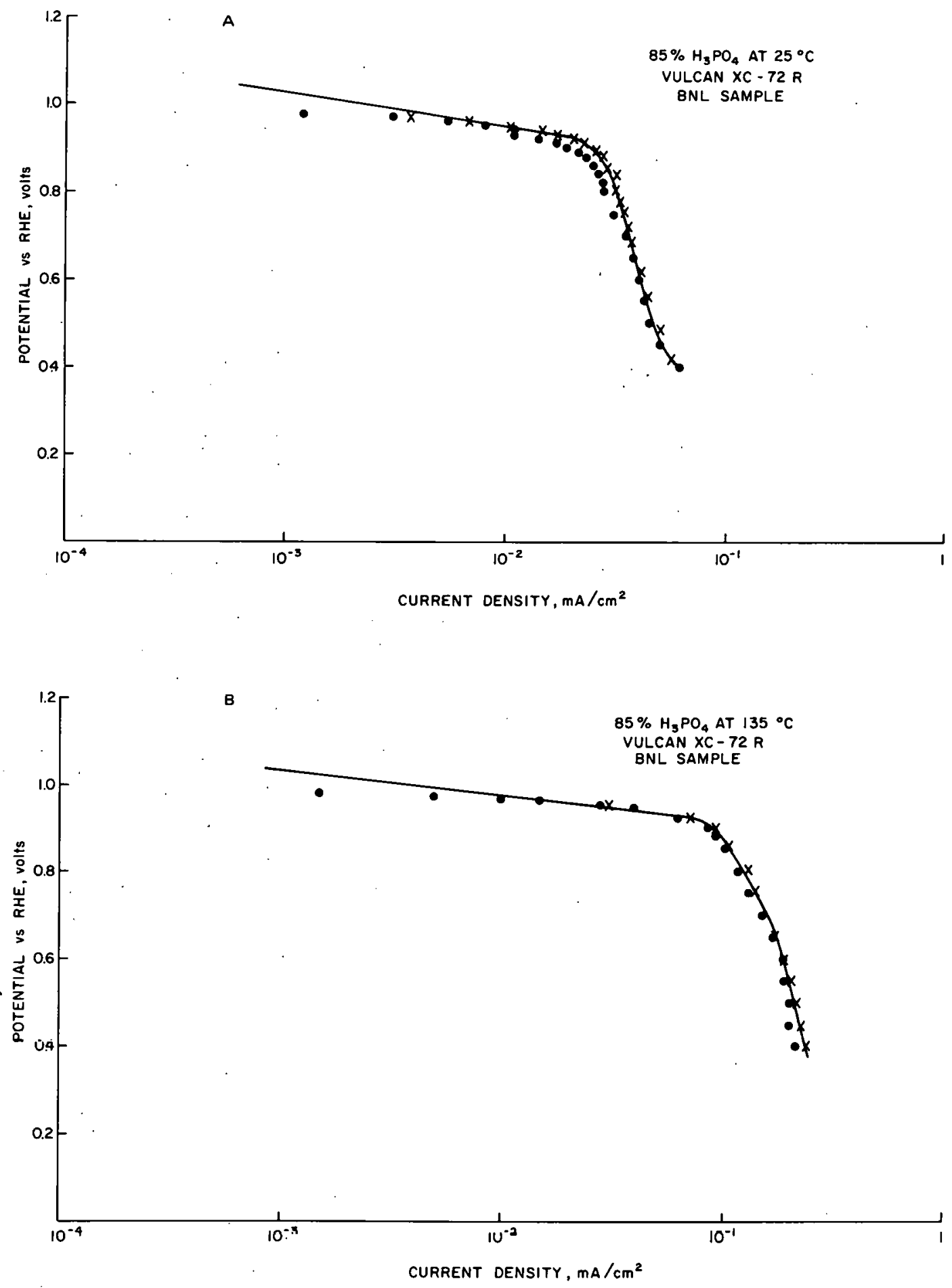

Figure 10. Current-Potential Behavior for Oxygen Reduction on BNL Prepared Vulcan XC-72R Supported Platinum Electrode in $85 \% \mathrm{H}_{3} \mathrm{PO}_{4}$ at (a) $25^{\circ} \mathrm{C}$ and (b) $135^{\circ} \mathrm{C}$. 


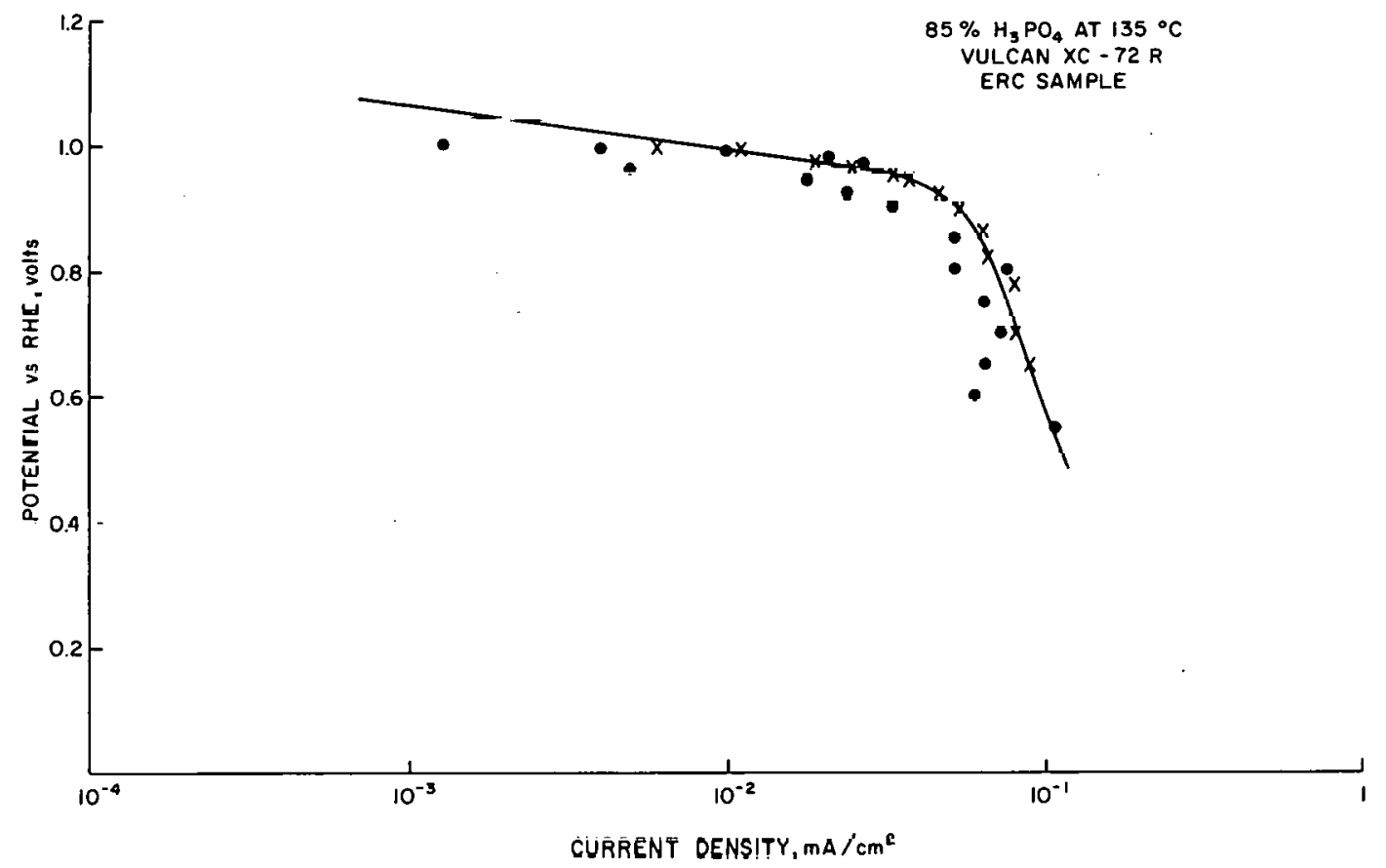

Figure 11. Current-Potential Behavior for Oxygen Reduction on ERC Prepared Vulcan $\mathrm{XC}-72 \mathrm{R}$ Supported Platinum Electrode in $85 \% \mathrm{H}_{3} \mathrm{PO}_{4}$ at $135^{\circ} \mathrm{C}$. 

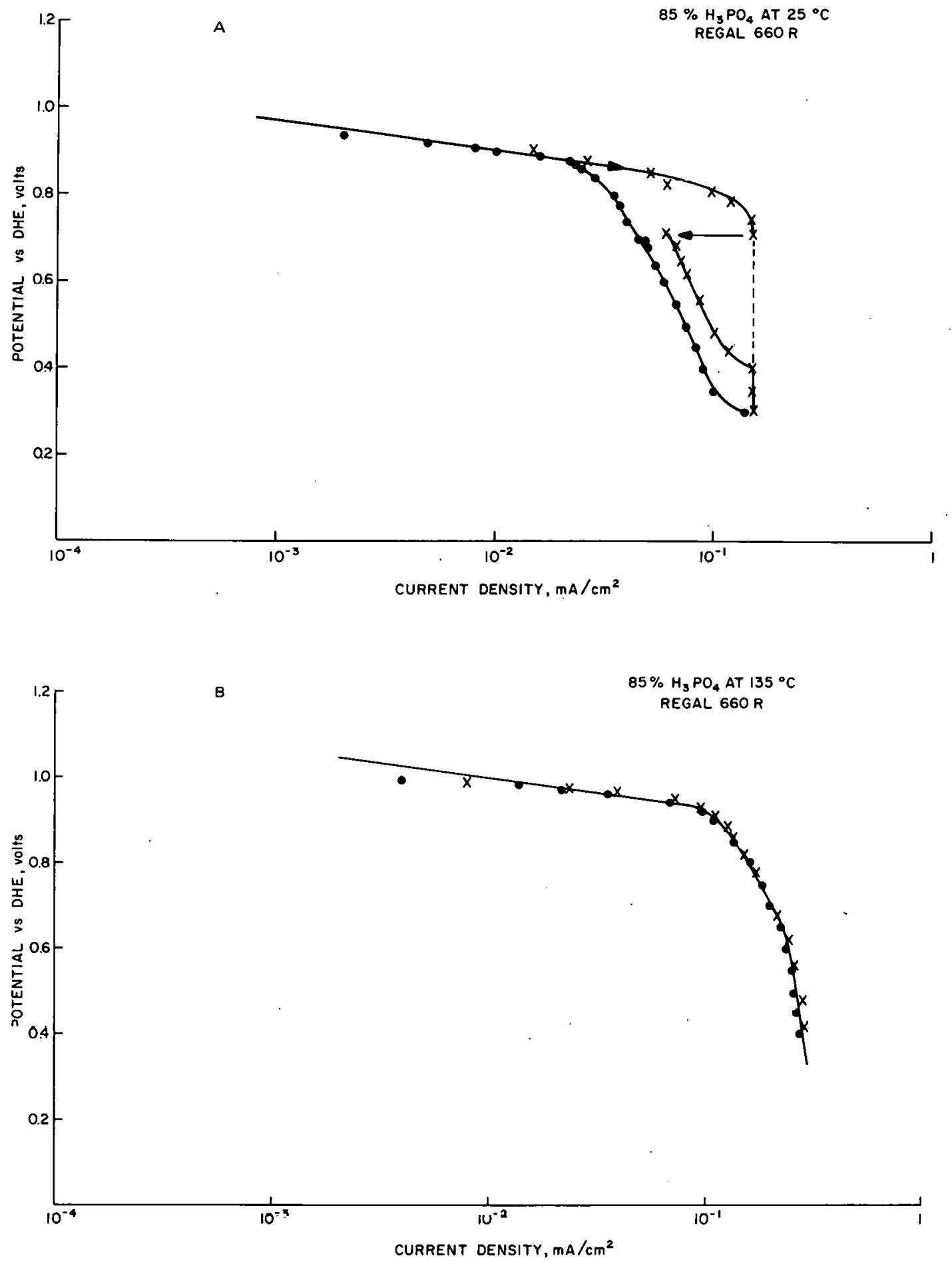

Figure 12. Current-Potential Behavior for Oxygen Reduction on Regal 660R Supported Platinum Electrode in $85 \% \mathrm{H}_{3} \mathrm{PO}_{4}$ at (a) $25^{\circ} \mathrm{C}$ and (b) $135^{\circ} \mathrm{C}$. 


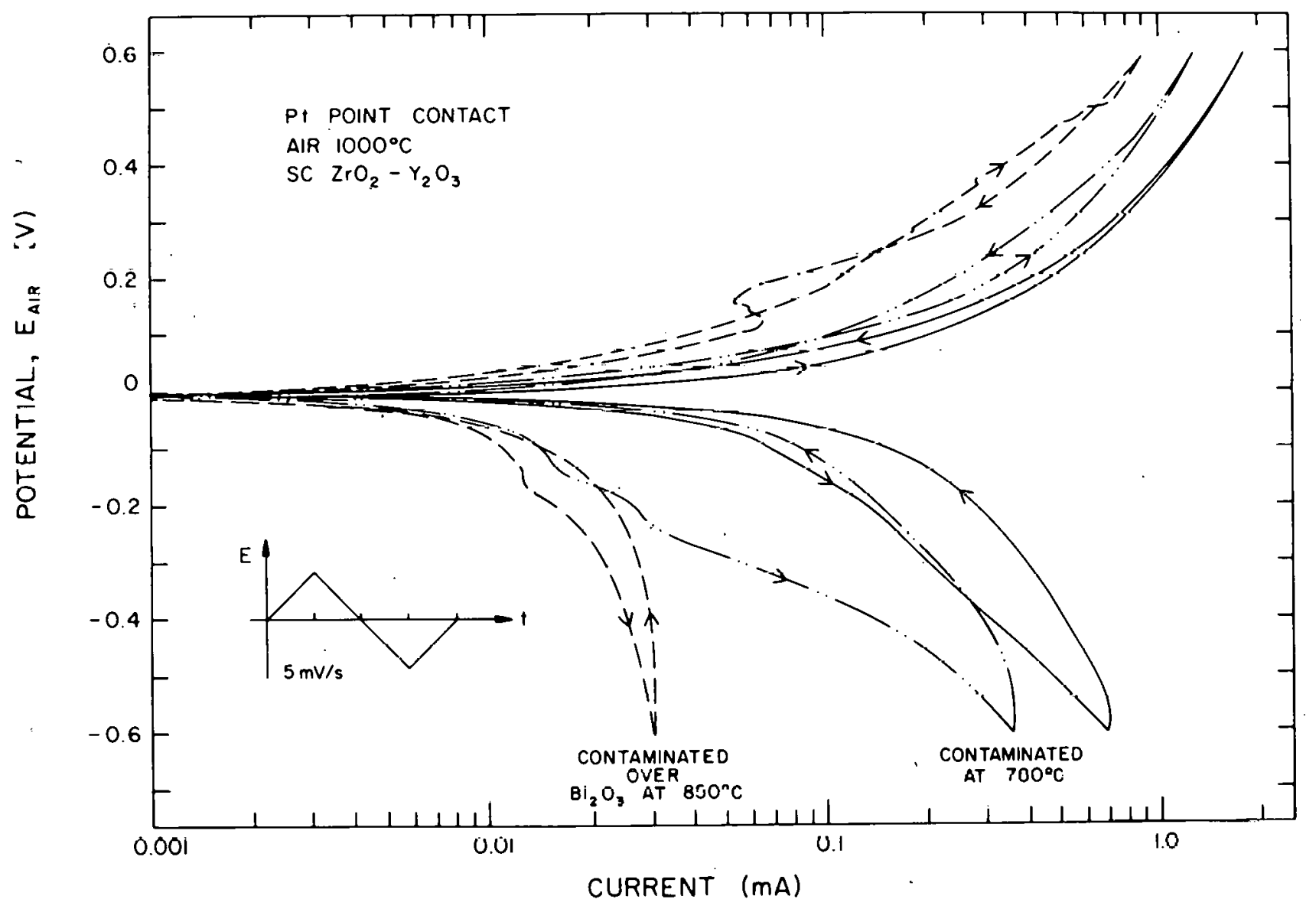

Figure 13. Polarization curves of a Platinum Puinl Cnntart Filectrode Before and After Exposure to $\mathrm{Bi}_{2} \mathrm{O}_{3}$ at $780^{\circ} \mathrm{C}$ and $850^{\circ} \mathrm{C}$, Respectively. Uncontaminated Platinum Point Electrode Shown for Comparison (Solid Line). 


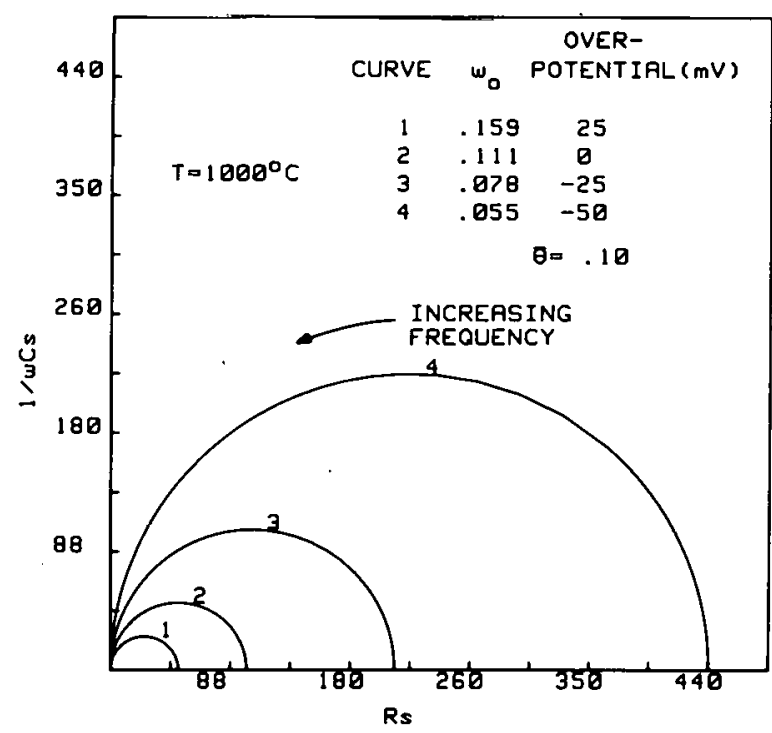

Figure 14. Reaction Impedance as a Function of Reaction Overpotential Resulting from a Rate Controlling Oxygen Adsorption Reaction. 


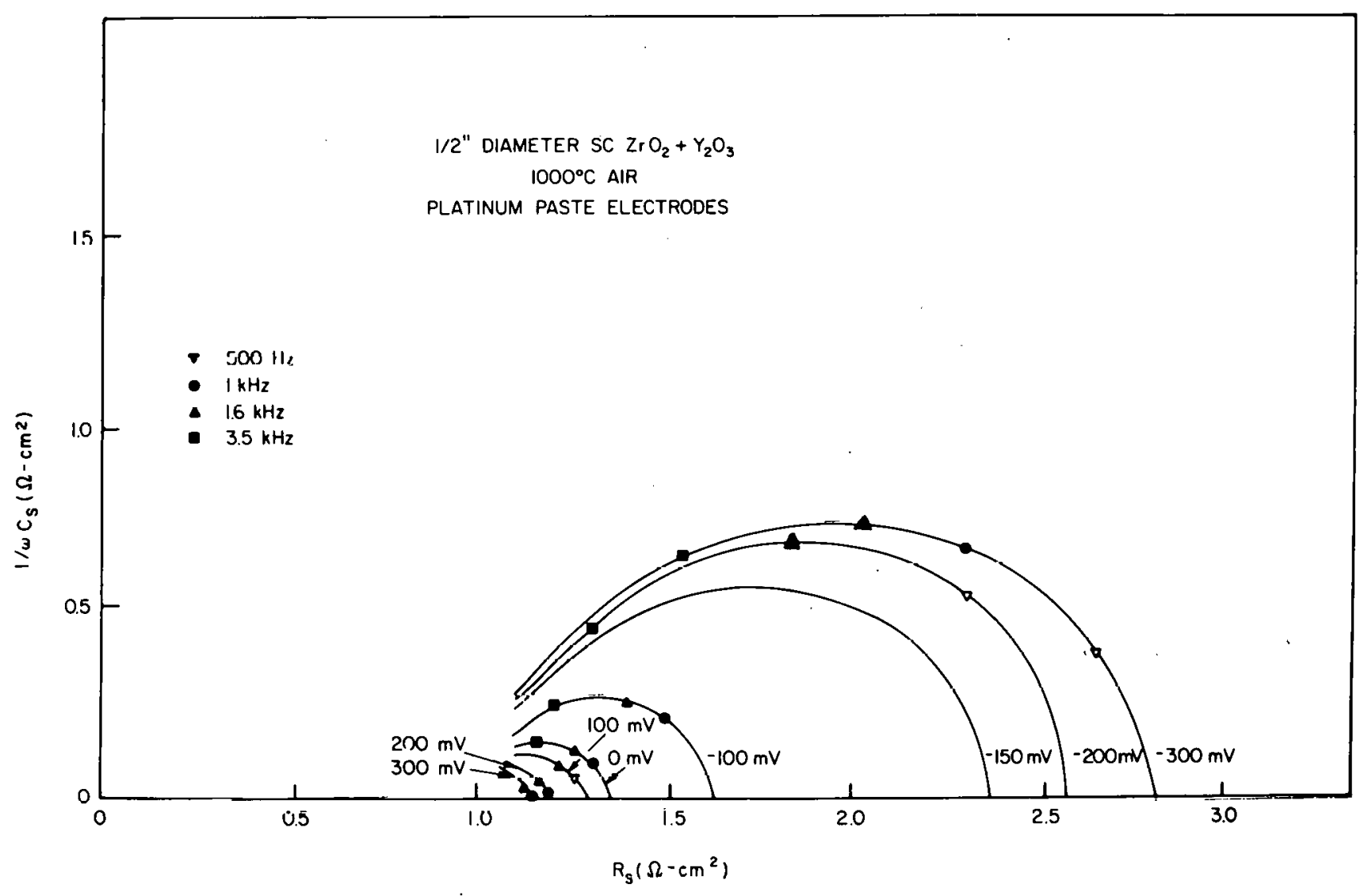

Figure 15. Potential Dependent Impedance Diagram of a flluxed Platinum paste Electrode Containing $\mathrm{Bi}_{2} \mathrm{O}_{3}$. 


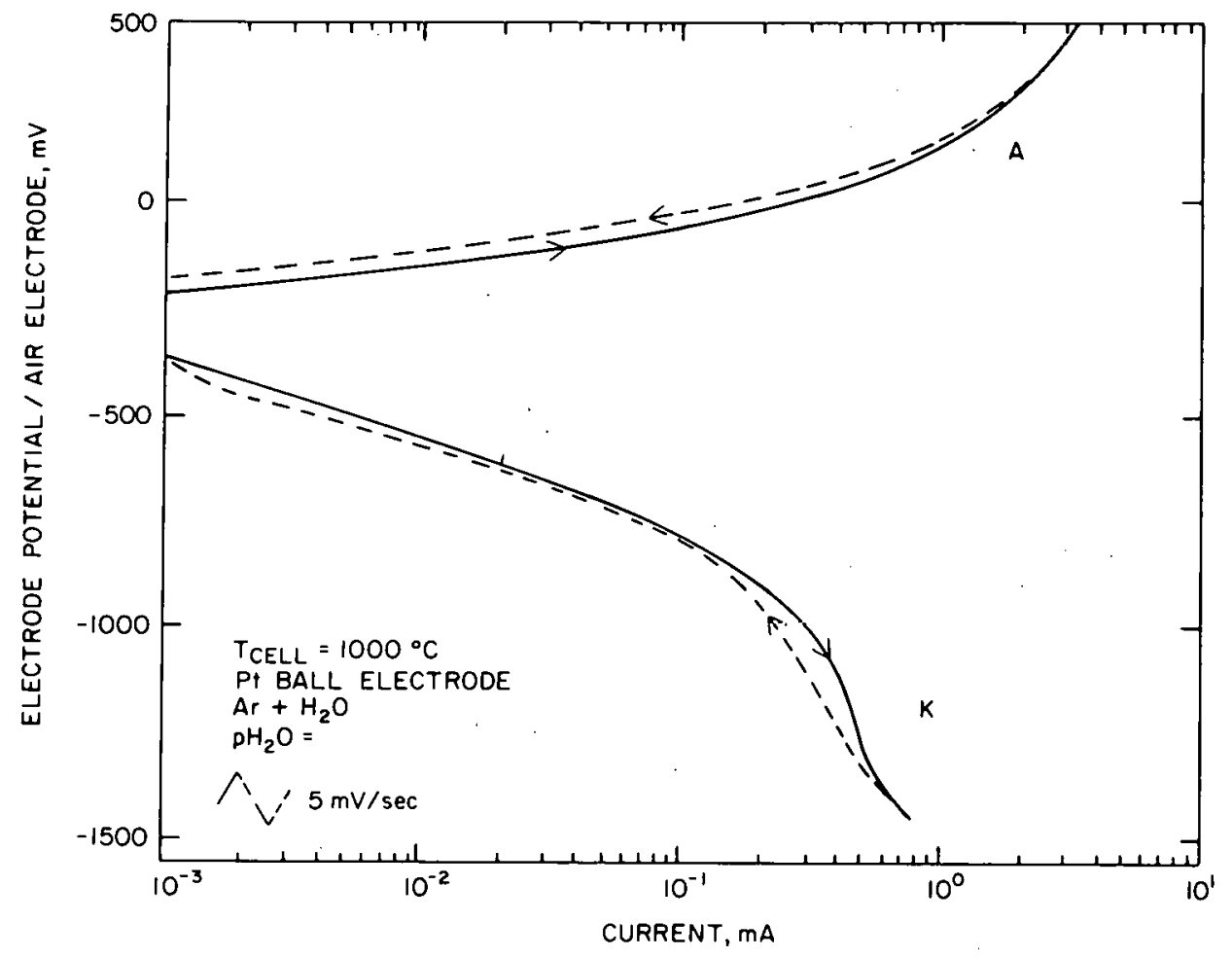

Figure 16a. Typical V vs Log I Curves Obtained with Pt "Ball Flectrode" at its Interface with $\mathrm{ZrO}_{2} / \mathrm{Y}_{2} \mathrm{O}_{3}$ Electrolyte in $\mathrm{Ar} / \mathrm{H}_{2} \mathrm{O}$ Mixtures. Temperature $1000^{\circ} \mathrm{C}$. 


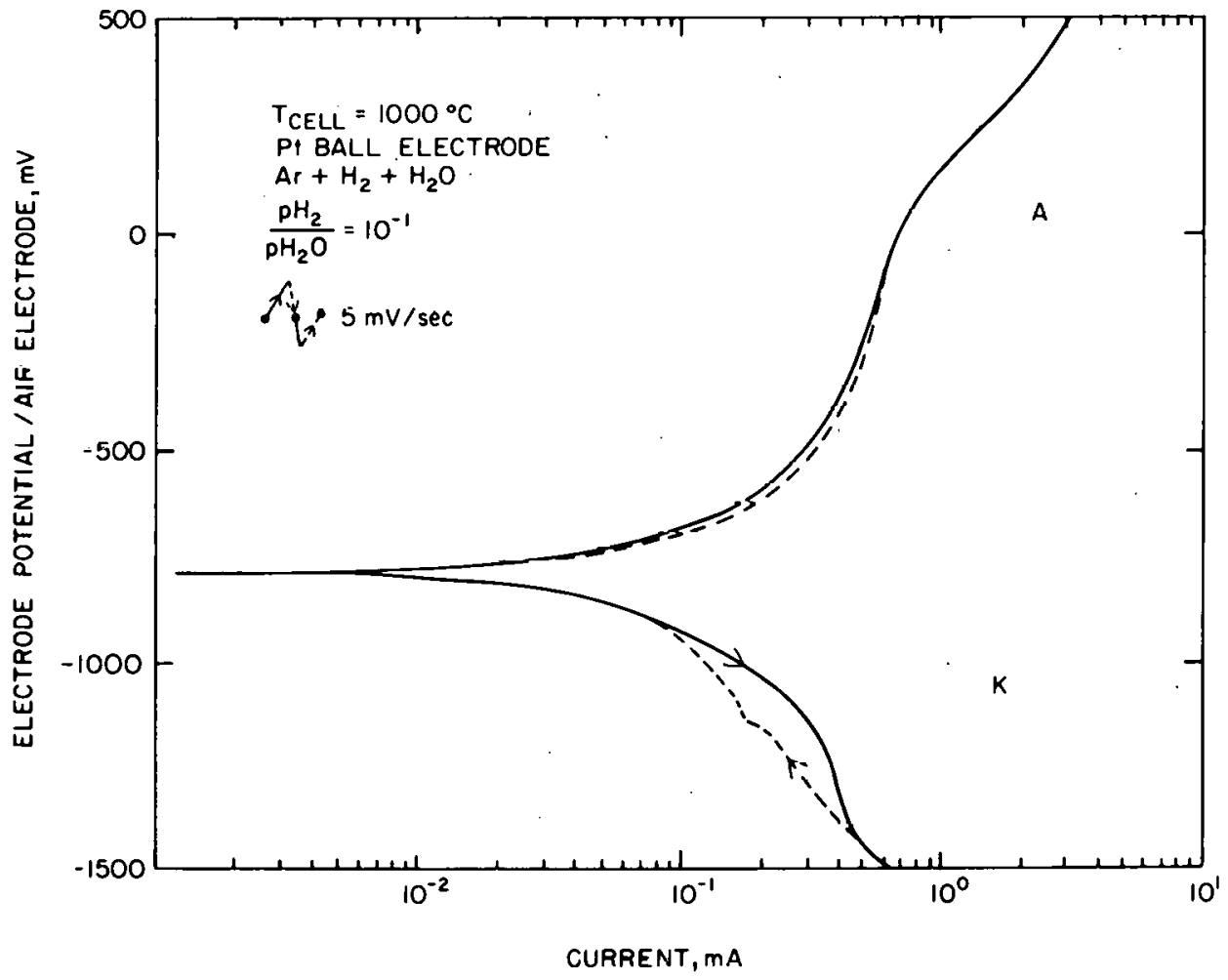

Figure 16b. Typical V vs Log I Curves Obtained with Pt "Ball Electrode" at its Interface with $\mathrm{ZrO} 2 / \mathrm{Y}_{2} \mathrm{O}_{3}$ Electrolyte in $\mathrm{Ar} / \mathrm{H}_{2} / \mathrm{H}_{2} \mathrm{O}$ Mixtures. Temperature $1000^{\circ} \mathrm{C}$. 


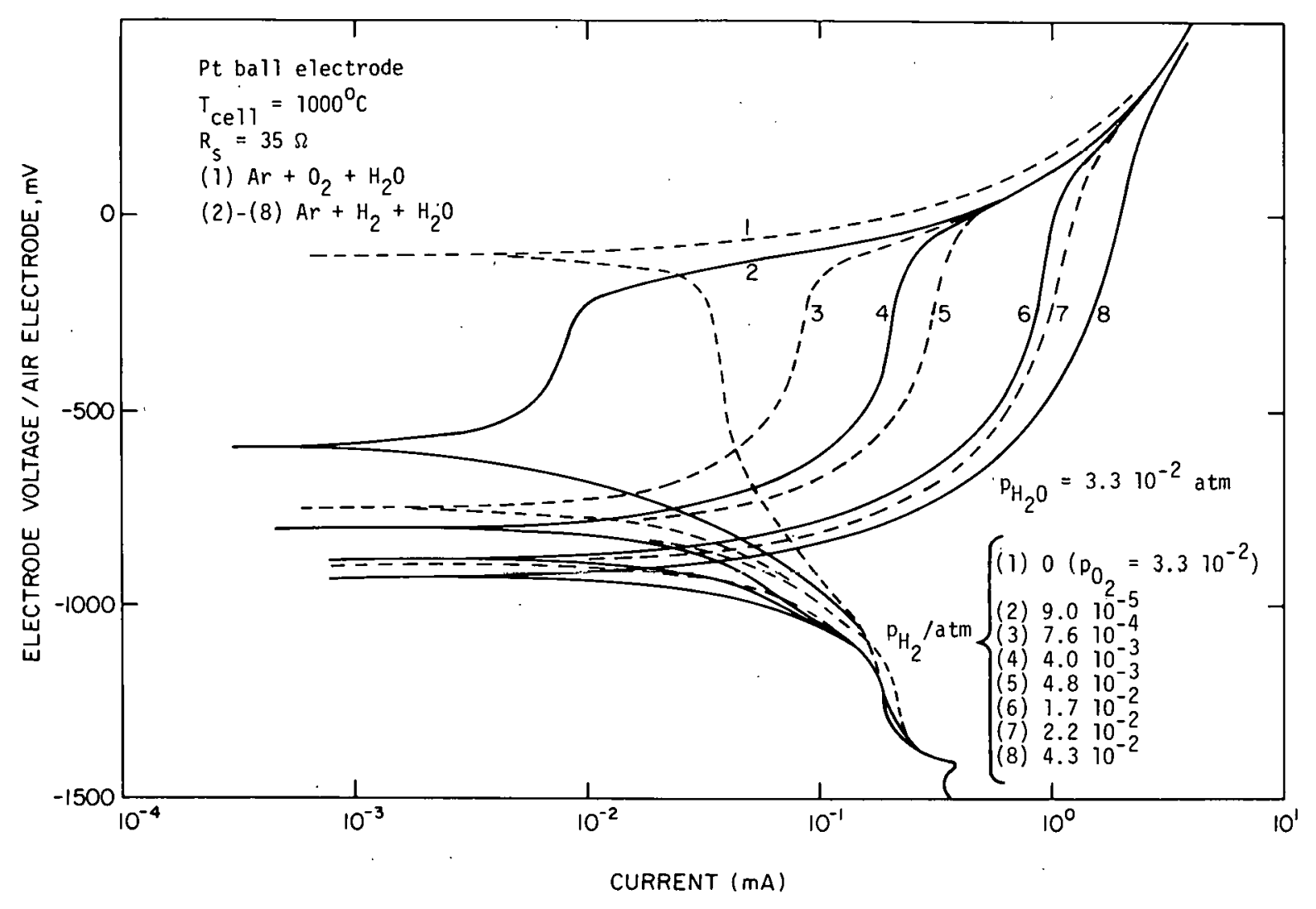

Figure 17. V vs Log I Curves for a Pt Electrode at its Interface with $\mathrm{ZrO}_{2} / \mathrm{Y}_{2} \mathrm{O}_{3}$ Electrolyte at Constant $\mathrm{p}_{\mathrm{H}_{2} \mathrm{O}}$ and Varying $\mathrm{p}_{\mathrm{H}_{2}}$. Temperature $1000^{\circ} \mathrm{C}$. 


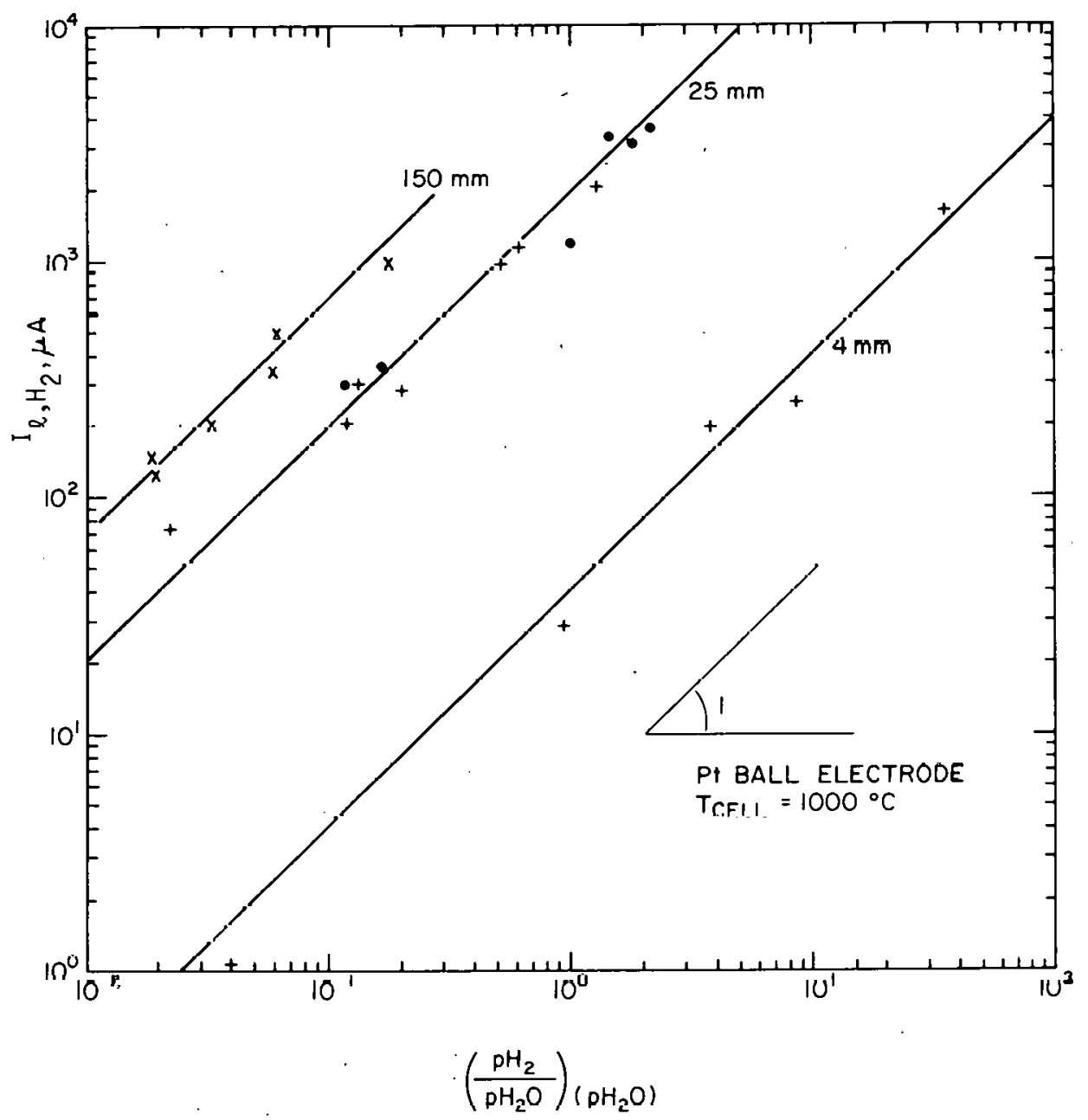

Figure 18. Dependence of $\mathrm{I}_{\ell, \mathrm{H}_{2}}$ for Different $\mathrm{p}_{\mathrm{H}_{2} \mathrm{O}}$ on a fil Ectrode at 1 ts Interface with $\mathrm{ZrO}_{2} / \mathrm{Y}_{2} \mathrm{O}_{3}$ Electrolyte. Temperature $1000^{\circ} \mathrm{C}$. 


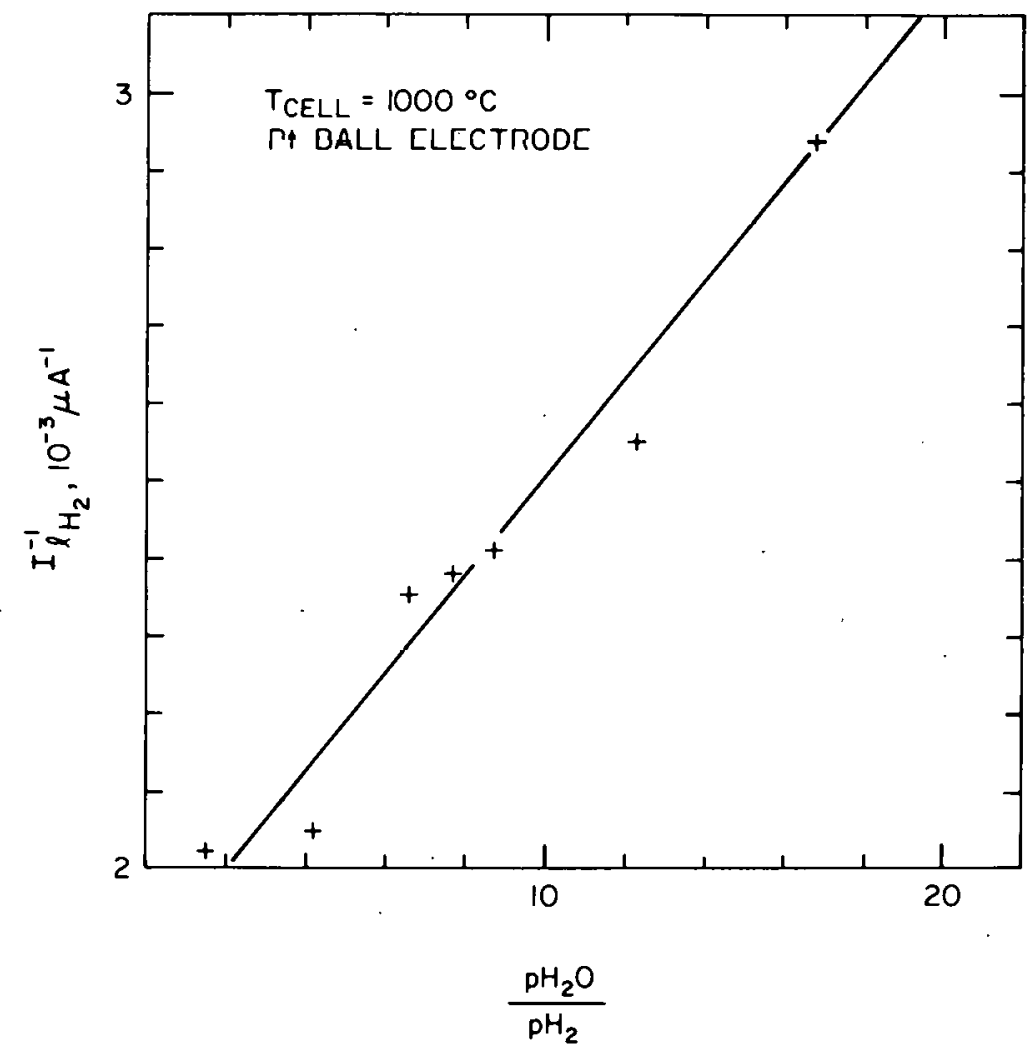

Figure 19. $\mathrm{I}_{\ell, \mathrm{H}_{2}}^{-1}$ vs $\mathrm{p}_{\mathrm{H}_{2} \mathrm{O}} / \mathrm{p}_{\mathrm{H}_{2}}$ Plots for a Pt Electrode at its Interface with $\mathrm{ZrO}_{2} / \mathrm{Y}_{2} \mathrm{O}_{3}$ Electrolyte. Temperature $1000^{\circ} \mathrm{C}$. 